\title{
Precambrian evolution of the climate system
}

\author{
James C.G. Walker \\ Space Physics Research Laboratory, Department of Atmospheric, Oceanic, and Space Sciences and Department of Geological \\ Sciences, The University of Michigan, 2455 Hayward, Ann Arbor, MI 48109 (U.S.A.)
}

(Received October 3, 1989; revised and accepted January 11, 1990)

\begin{abstract}
Walker , J.C.G., 1990. Precambrian evolution of the climate system. Palaeogeogr., Palaeoclimatol., Palaeoecol. (Global. Planet. Change Sect.), 82: 261-289.
\end{abstract}

Climate is an important environmental parameter of the early Earth, likely to have affected the origin and evolution of life, the composition and mineralogy of sedimentary rocks, and stable isotope ratios in sedimentary minerals. There is little observational evidence constraining Precambrian climates. Most of our knowledge is at present theoretical. Factors that must have affected the climate include reduced solar luminosity, enhanced rotation rate of the Earth, an area of land that probably increased with time, and biological evolution, particularly as it affected the composition of the atmosphere and the greenhouse effect. Cloud cover is a major uncertainty about the early Earth. Carbon dioxide and its greenhouse effect are the factors that have been most extensively studied.

This paper presents a new examination of the biogeochemical cycles of carbon as they may have changed between an Archean Earth deficient in land, sedimentary rocks, and biological activity, and a Proterozoic Earth much like the modern Earth, but lacking terrestrial life and carbonate-secreting plankton. Results of a numerical simulation of this transition show how increasing biological activity could have drawn down atmospheric carbon dioxide by extracting sedimentary organic carbon from the system. Increasing area of continents could further have drawn down carbon dioxide by encouraging the accumulation of carbonate sediments. An attempt to develop a numerical simulation of the carbon cycles of the Precambrian raises questions about sources and sinks of marine carbon and alkalinity on a world without continents. More information is needed about sea-floor weathering processes.

\section{Introduction}

What properties of the environment made possible the origin of life on Earth? How did the properties of the environment influence the course of biological evolution early in Earth history? Our present world is a consequence of the way the world once was. It is therefore important to seek a clearer understanding of the environment of the early Earth. The properties of interest include physical ones such as temperature and illumination as well as chemical ones such as the composition of ocean and atmosphere. Study of Precambrian climate involves both physical properties and, because of the greenhouse effect, chemical properties.

Knowledge of the climates of the Precambrian Earth is at present very limited. Some information can be derived from sedimentary rocks, but the interpretation of the evidence is not yet clear. The isotopic composition of the oxygen in sedimentary minerals, principally carbonates and cherts, has attracted interest. Measurements of the isotopic composition indicate that temperatures were high in the Precambrian (Knauth and Epstein, 1976; Knauth and Lowe, 1978; Karhu and Epstein, 1986) if it is assumed that the oxygen isotopic composition of sea water was the same then as it is now (Kolodny and Epstein, 1976; Muehlenbachs and Clayton, 1976; Gregory and Taylor, 1981) and if it is further assumed that the minerals being studied have not suffered alteration by diagenesis at temperatures higher than those of the surface. These assumptions are hardly likely to be correct (Perry and Tan, 1972; Perry and 
Ahmad, 1983; Walker and Lohmann, 1989). I suggest that oxygen isotopic measurements do not yet provide significant constraints on surface temperatures in the Precambrian.

An alternative source of information is provided by the sedimentological evidence for continental glaciation. This evidence has been reviewed by Walker et al. (1983) and Hambrey and Harland (1981). There are no unambiguous glaciogenic deposits of Archean age (older than $2.5 \times 10^{9} \mathrm{yr}$ ). There is widespread evidence of continental glaciation on essentially all of the continents in Huronian times, about $2.3 \times 10^{9} \mathrm{yr}$ ago, and again in the Late Proterozoic between about 800 and $600 \times 10^{6}$ yr ago (Mustard and Donaldson, 1987; Stump et al., 1988; Harker and Giegengack, 1989). In the long intervening time period extending over more than $10^{9}$ years, there is no clear evidence of continental glaciation. Taken at face value, this evidence would seem to suggest that the Precambrian Earth was generally warm, but that the climate system very infrequently allowed glacial conditions to develop. In this respect, the Precambrian climate apparently resembles the climate of Phanerozoic Earth history, which has been characterized by brief periods of widespread continental glaciation separated by long periods of time during which the climate was apparently warmer (Frakes, 1979). But even here, the evidence is ambiguous. It has recently been argued by Frakes and Francis (1988) that ice was present in the polar regions throughout the Phanerozoic. There may have been no times in the last $600 \times$ $10^{6} \mathrm{yr}$ of Earth history when the planet was largely free of ice. The ice ages that show up so anomalously in the rock record may be a result of preservational anomalies or may reflect very minor perturbations of the climate system. By extension, then, the $10^{9}$ years of warm Proterozoic climate between the Huronian glaciation and the Late Proterozoic glaciation may not have been all that warm.

Reliable information on the paleolatitudes of the Precambrian glaciations is sparse. It has been reported that the Late Precambrian glaciations occurred during a time when all the continents were at low latitudes (Walter, 1979), but because the glacial deposits are intermittent, the overall period of time, $200 \times 10^{6} \mathrm{yr}$, is long, and because continents move relatively rapidly, it is by no means clear that the continents were at low latitudes when they were covered with ice.

Constraints on paleoclimate are, of course, imposed by the existence of terrestrial life. We can be reasonably confident that annual average temperatures were between the freezing and boiling points of water at the times, places, and pressures where life existed. It is hard to set tighter constraints than these in the Precambrian when life was largely bacterial, because bacteria can flourish even under severe environmental conditions (Brock, 1978, 1985). The oldest clear evidence of life dates from $3.5 \times$ $10^{9}$ yr ago (Schopf and Walter, 1983; Walter, 1983; Walsh and Lowe, 1985; Awramik, 1986; Byerly et al., 1986; Schopf and Packer, 1987). By that time, Earth was neither too hot nor too cold for bacterial life. The subsequent Archean record of life is fragmentary (Walker, 1990). From time to time there were habitable places on Earth, but the fossil record does not prove without doubt that all of Earth was continuously habitable during the entire Archean. In contrast, the Proterozoic record provides strong evidence for continuous habitation. Proterozoic climates were probably never too extreme for life.

We can expect observational information on Precambrian climates to improve and the interpretation to become more secure. For the time being, the study of Precambrian climates must depend heavily on theoretical argument and analysis. This paper describes some of the factors that must be considered in theoretical treatments of Precambrian climate and offers a completely new treatment of the geochemical factors that might have influenced the partial pressure of carbon dioxide, important because of its greenhouse effect. Previous reviews of paleoclimatology including the Precambrian have been presented by Frakes (1979) and by Crowley (1983). A review devoted specifically to the unusual features of the Precambrian climate system was published by Walker (1982). More recently, Kuhn et al. (1989) have provided a 
quantitative treatment of these factors by means of an energy balance climate model.

\section{Factors affecting Precambrian climate}

\section{Solar luminosity}

This factor has been discussed many times since its climatic significance was first explored by Ringwood (1961) and by Sagan and Mullen (1972). As a main sequence star like the sun consumes its nuclear fuel, converting hydrogen nuclei to helium nuclei, the increase in nuclear mass yields denser material at a given temperature. The balance of pressure gradient and gravitational forces results in a higher pressure in the center of the star, compression of the gas yields a higher temperature, nuclear reactions are faster at higher temperatures because the Coulomb repulsion between positively charged nuclei is more easily overcome at high temperatures, so the rate of generation of nuclear energy within a main sequence star increases as it ages. Energy does not accumulate within the star, so its luminosity increases with time. The predicted increase is too slow to be directly observed. It is entirely a theoretical result and may therefore be wrong. It is not a result that depends on esoteric details of stellar models, however. If it is wrong, there must be a fundamental flaw in our understanding of the physics of stars.

The rate of increase of luminosity is much less certain than the fact that increase has occurred, because it depends on just how much of sun's hydrogen has already been converted to helium. The best estimate is an increase in luminosity by about $30 \%$ of its present value over the age of the solar system (Gough and Weiss, 1976; Newman and Rood, 1977; Gough, 1977). Clearly, such a reduction in solar luminosity would have caused the Earth to freeze over if other aspects of the climate system had remained unchanged. But there is no evidence for such a global ice catastrophe. While the possibility of intermittent unrecorded glaciations must be admitted, there clearly were unfrozen episodes during which water-borne sediments were deposited and microbial ecosystems flourished. An abundant record of well-preserved sedimentary rocks begins about $2.5 \times 10^{9} \mathrm{yr}$ ago, in the Proterozoic. We can probably be confident that the Earth has not frozen over completely, even briefly, since that time. Other aspects of the climate system must therefore have compensated for reduced solar luminosity.

The properties of the climate system that have been seriously considered as offering a solution to the problem of the faint young sun are the atmospheric greenhouse and planetary albedo. Suggestions concerning these properties are discussed below.

\section{Rotation rate}

Gravitational torque between the moon and the tides it raises on Earth transfers angular momentum from Earth's rotation to the moon's orbit. As a result, the moon moves away from the Earth and the Earth's rate of rotation decreases. This transfer of angular momentum results in a decrease in the kinetic energy of the Earth-Moon system, and the rate of orbital evolution depends on the rate of dissipation of energy by turbulent motions and friction in the tides. It is a straightforward matter to calculate the evolution for a specific assumption concerning the rate of energy dissipation. For example, it may be assumed that the fraction of tidal energy dissipated per tidal cycle, $Q$, is constant. Extrapolation of present rates of evolution back into the past, using this assumption, results in the moon impossibly close to the Earth only $1.8 \times 10^{9}$ yr ago. Such a prediction is inconsistent with the geological record which reveals no global catastrophes during the Proterozoic. Specific energy dissipation rates must have been smaller in the past for reasons not well understood. A simple assumption that yields orbital evolution consistent with the rock record is constant specific energy dissipation rate during the Phanerozoic at the modern value and a constant but smaller rate during the Precambrian. A Precambrian rate one-third as large as the Phanerozoic rate results in the moon being close to the Earth at the time of formation of the 
solar system. This assumption yields a useful first approximation to the orbital evolution of the Earth-Moon system (Fig. 1).

According to this scenario, the day may have been as short as four hours when Earth first formed, but by $4 \times 10^{9}$ yr ago daylength had already increased to about 13 hours. It increased gradually through the rest of the Precambrian to about 21 hours at the end of the Proterozoic, $600 \times 10^{6} \mathrm{yr}$ ago, and then more rapidly to the present value. This history of Earth's rate of rotation is most reasonable. The only observation that is sufficiently ancient to test the Precambrian history is a very speculative interpretation by Walker and Zahnle (1986) of rhythmically banded sediments with an age of $2.5 \times 10^{9}$ yr (Trendall, 1973). The interpretation assumes that the millimeter thick bands are annual deposits, a response of the depositional system to seasonal change. A regular oscillation of the thickness of the bands with an apparent period of $23.3 \mathrm{yr}$ is then interpreted as a response of the

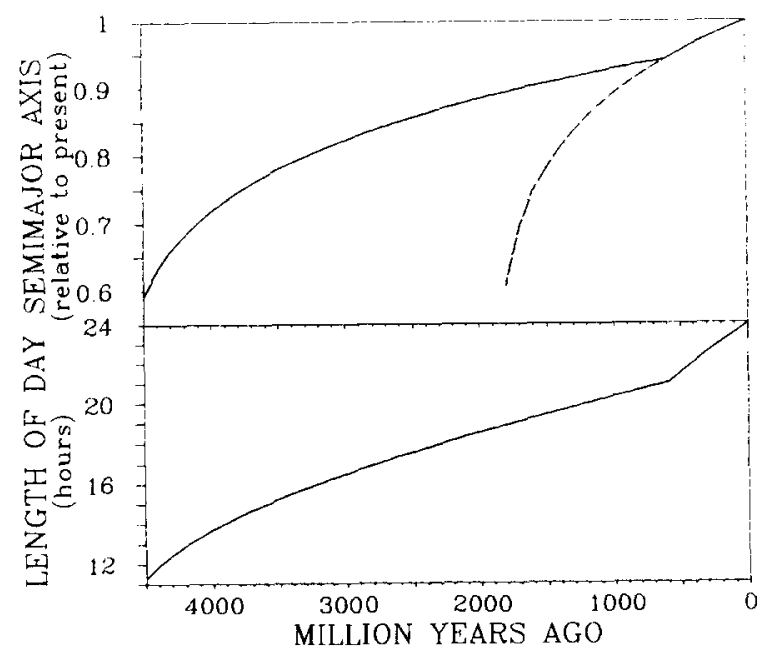

Fig. 1. Evolution of the semimajor axis of the lunar orbit and the corresponding length of the day. The dashed line in the upper panel shows the close approach of the moon less than 2000 million years ago that results from the assumption of constant specific energy dissipation rate. The solid line shows a plausible evolutionary history in which the specific energy dissipation rate is smaller in the Precambrian than in the Phanerozoic. The length of day is calculated under the assumption of constant angular momentum in the EarthMoon system.

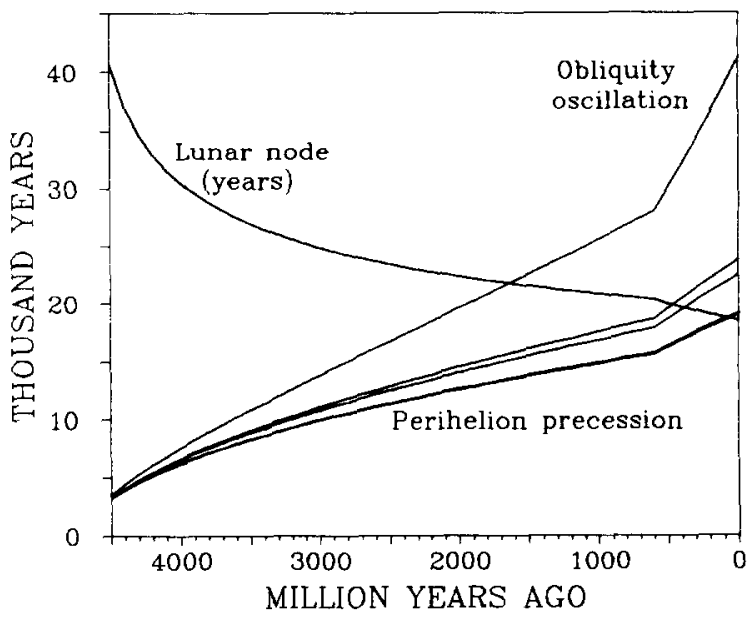

Fig. 2. Evolution of periodicities associated with lunar orbit. The period of the lunar nodal tide is measured in years; the periods of obliquity oscillation and perihelion precession are measured in thousands of years. There are four rather similar periods of perihelion precession shown in the figure. The periods of the eccentricity oscillation (not shown) remain constant at about 105 and $400 \times 10^{3} \mathrm{yr}$.

climate-sediment system to the lunar nodal tide (Fig. 2). If this interpretation is correct, the observation confirms the history of evolution of the Earth-Moon system described above.

An alternative history has, however, been described by Zahnle and Walker (1987). These authors note that the thermal tide in the atmosphere generated by solar heating could achieve a very large amplitude at resonance, when the daylength corresponds to a period of free oscillation of the atmosphere. One such free oscillation period is about $21 \mathrm{~h}$, so a resonance would be expected when the length of the day was $21 \mathrm{~h}$. Gravitational interaction between the large atmospheric tide and the sun could then feed angular momentum from Earth's orbit into Earth's rotation that could, in principle, sustain the length of the day for as long as the resonance survived. In principle, according to these ideas, the length of the day could have evolved rapidly during the Archean until the resonance period of about $21 \mathrm{~h}$ was achieved. The solar tidal interaction could then have kept the length of the day constant throughout the Proterozoic until a chemically induced change in the thermal structure of the atmosphere moved the nat- 
ural tidal period of the atmosphere to shorter values, away from the resonance, freeing the system to evolve in the more familiar manner under the influence of lunar tidal torques. While daylength would have been constant, according to this hypothesis, the moon would have been receding steadily from the Earth, the EarthMoon system gaining angular momentum from Earth's orbit. Apart from its implications concerning the history of daylength, this hypothesis would imply that there was a time of exceptionally large amplitude of the diurnal thermal tides. Zahnle and Walker (1987) speculate that the tidal amplitudes may have been large enough to have influenced the weather, especially in the tropics. There is, at present, no evidence of resonant atmospheric tides in Earth history; neither is there any evidence against them.

Daylength is directly relevant to the climate system because of its influence on the Coriolis parameter. Hunt $(1979 a, b)$ has used a general circulation model to examine the consequences of an increase in rotation rate by a factor of 5 . Note that this increase is too large to apply to most of the Precambrian period, in particular that period of the Precambrian from which sedimentary rocks survive. As discussed above, there is no reason to expect a rotation rate increased by more than a factor of 2 since the onset of the sedimentary rock record $3.8 \times 10^{9}$ yr ago. Nevertheless, Hunt's pioneering work should provide an indication of how the climate system might respond to enhanced rotation rates. He reports that the characteristic scale of motion in his general circulation model is reduced at high rotation rates, and wind stress is reduced with possible implications for ocean currents and vertical mixing in the ocean. The velocity of the jet stream decreases and its latitude decreases also. Meridional transport also decreases and the difference between average temperatures at the equator and the poles increases. As a consequence of the temperature decrease at high latitudes, precipitation decreases at high latitudes also and the subtropical arid zones move closer to the equator.

Kuhn et al. (1989) have also investigated the effect of higher rotation rate on the meridional temperature distribution using an energy balance climate model with the nonlinear transport parameter developed by Stone (1972). This work reports significant increases in the equator-topole temperature differences in the Precambrian even though the increase in rotation rate does not exceed a factor of 1.8. The influence of increased rotation rate on the climate system plainly merits further investigation. A group at the University of Michigan is now embarking on such a study using the Community Climate Model of the National Center for Atmospheric Research.

In a comment on Hunt's work, Williams (1980) suggested that change in the obliquity of Earth's equator relative to the orbital plane might be of more climatic significance than change in the rotation rate. As noted by Hunt (1980), in his response, there is no known mechanism of obliquity change other than gravitational interactions with the moon, which depend on the lunar distance and therefore are closely coupled to the evolution of the Earth-Moon system. The question was reexamined by Zahnle and Walker (1987) who found that obliquity could have been as small as $20^{\circ}$ some $4 \times 10^{9}$ yr ago when the lunar distance was at least 45 Earth radii and the daylength at least $12 \mathrm{~h}$. Since that time obliquity has been increasing steadily to its present value of $23^{\circ}$. There are at present no grounds for exploring the influence of large obliquities on terrestrial climates except in applications to the first few hundred million years of Earth history, long before the beginning of the rock record.

There are reports of cyclically banded sediments of Precambrian age that might record Milankovitch periodicities associated with oscillations in Earth's orbital elements in the 10-100 $\times 10^{3}$ yr period range (Trendall, 1983; Grotzinger, 1986; Veevers and Powell, 1987). As noted by Hallam (1986) and by Algeo and Wilkinson (1988) there is some tendency for every cyclically banded sediment that is readily apparent in the field to look as though it has a Milankovitch periodicity, so reported observations must be treated with caution (Mix, 1987). However, an accurate determination of a Milankovitch 
period in the Precambrian would provide a definite measure of the Earth-Moon distance and therefore of the daylength (if conservation of angular momentum is assumed for the EarthMoon system). The evolution of Milankovitch cycles as a consequence of evolution of the Earth-Moon system has been examined by Walker and Zahnle (1986) and more recently by Berger et al. (1989). The period of $105 \times 10^{3} \mathrm{yr}$ is associated with oscillations in the eccentricity; this period is not expected to change over the life of the solar system. By contrast, both the $41 \times 10^{3}$ yr obliquity and the $23 \times 10^{3} \mathrm{yr}$ precession cycle depend in part on the precession of Earth's axis of rotation with respect to the fixed stars. This precession results from lunar and solar torques on Earth's equatorial bulge. The lunar torque changes as the moon moves away from the Earth and the equatorial bulge changes as the Earth's rate of rotation decreases. With allowance for these effects, Walker and Zahnle calculate that the obliquity period might have been $17 \times 10^{3} \mathrm{yr}$ and the precession period might have been $13 \times 10^{3} \mathrm{yr}$ at the end of the Archean, when daylength might have been $15 \mathrm{~h}$ (Fig. 2).

\section{Land area}

There is a considerable body of evidence, geochemical, geophysical, sedimentological, and isotopic for growth and differentiation of the continents sometime after the origin of Earth, ocean, atmosphere, and life. The subject has been extensively reviewed (Veizer, 1983; Taylor and McLennan, 1985; Harley, 1987; Nisbet, 1987; Bickford, 1988; Goldstein, 1988; Veizer, 1988, 1989); there is disagreement about the significance of the data (Gurnis and Davies, 1986; Jacobsen, 1988; Bowring et al., 1989; Hoffman, 1989); my own view is that the continents were relatively small both in volume and in area prior to $3 \times 10^{9}$ yr ago, that growth was relatively rapid between 3 and $2 \times 10^{9} \mathrm{yr}$ ago, and that growth since then has continued, but at a slower rate (Veizer and Jansen, 1979; Condie, 1986, 1989; Pollack, 1986; Nisbet, 1987). While even this qualitative history may be in error, the working of the climate system on a planet with an ocean but with little or no dry land is certainly of interest, unless the continents developed at essentially the same time as Earth, ocean, and atmosphere.

Land area affects the climate system directly because the albedo of land is different from that of ocean (Thompson and Barron, 1981). The influence of the albedo change caused by continental growth has been investigated by Kuhn et al. (1989) using an energy balance climate model. They find that the albedo change is not nearly as important to the climate system as changes in rotation rate, solar luminosity, or atmospheric greenhouse. They key element in albedo, of course, is cloud cover. With approximately half of Earth's surface covered by bright, white clouds, the relatively small differences in albedo between land and ocean on the other 50\% of the surface have little effect on the total planetary albedo. Of potentially greater importance is the influence of land area on cloud cover. This effect was incorporated in the study of Kuhn et al. (1989), who used present day values for cloud cover, distinguishing between land and ocean. Henderson-Sellers (1978) has also used modern observations to distinguish between cloud cover over land and cloud cover over the oceans. More work along these lines is needed, but empirical results for the present system may not apply to the very different climatological situations of the Precambrian. With that precaution in mind, I note that Kuhn et al. (1989) found little influence of land area on climate, even with allowance for different cloud cover on land and at sea.

Apart from changes in albedo, growth of the continents could have effects on the climate system that are not susceptible to study by the energy balance climate model of Kuhn et al. (1989). These include the seasonality associated with large land masses, monsoon circulations, and standing waves. The growth of continents should also affect the circulation of the ocean and the energy transport associated with this circulation. The implications of these possible influences on Precambrian climate are not at present known. Here is another set of problems 
that could usefully be studied with a general circulation model. The interactive coupling of atmospheric and oceanic general circulations is apparently very difficult, but it might be easier on a globe completely covered by a uniform ocean.

Still another area in which continental growth may have affected the climate system is atmospheric composition. In particular, the geochemical cycles of carbon on the modern Earth are heavily influenced by continental interactions. Markedly different geochemical cycles, carbon dioxide partial pressure, and greenhouse effect would be expected on a world without continents (Walker, 1983, 1985). These changes are explored in more detail below.

In addition, the growth of continental area may have influenced the abundance and the geochemical power of life. Knoll (1979) has suggested that early photosynthetic organisms were largely restricted to life on the bottoms of shallow water bodies. The fossil remains of early life are mostly stromatolites, which plainly formed at the interface between sediment and water. Microfossils of Archean organisms are also quite likely of benthic rather than planktonic organisms. The growth of continental platforms with associated shallow seas on the continental shelves would have provided increased area for colonization by early life; these continental platforms would have had the added advantage of tectonic stability and long lifetimes in geological terms compared with the unstable volcanic islands which were the original forms of dry land. For these reasons, Knoll (1979) suggested that the growth of continents might have been accompanied by a great expansion in the global biota and a much increased geochemical role for life.

\section{Biological developments}

The most important geochemical role for life was then as it is now as a source of oxygen (Walker, 1984a). The transition from the early anaerobic environment to an oxidizing ocean and atmosphere occurred early in the Proterozoic, from approximately 2.3 to $1.7 \times 10^{9}$ years ago (Cloud, 1968, 1973). Evidence concerning this transition has been reviewed by Walker et al. (1983; Twist and Cheney, 1986). The transition took place when the rate of release of oxygen by photosynthetic organisms became larger than the rate of release of reactive reduced species like dissolved iron and volcanic hydrogen. The transition may have been caused by a decline in the rate of release of reduced species (Walker, 1978 ) or by an increase in the rate of photosynthesis, or both. Knoll (1979) suggested that it occurred at about the same time as the growth in the continental area as a consequence of the stimulus to the biota provided by greatly expanded stable, shallow-water habitats.

From time to time speculations appear in the literature that the early Earth was not deficient in oxygen (Dimroth and Kimberley, 1976; Dimroth and Lichtbau, 1978; Towe, 1978, 1981, 1983). In my own view, there is no process that could have rendered the Earth oxygen-rich before the origin of life and photosynthesis, so there is no question that the prebiological Earth was anaerobic. Moreover, the origin of life must have occurred in an anaerobic environment and may have occurred in the hydrosphere or atmosphere. In addition, I find the geological evidence concerning the transition, including banded iron-formations, uraninite ores, paleosols, and redbeds persuasive, when considered together. The oxygenic transition did indeed occur, as a consequence of biological activity, although there may be some uncertainty about when it occurred and precisely what caused the biological sources of oxygen to prevail over the abiological sources of reduced matter.

Climate consequences of the development of life and of an oxygenic environment might include the reduction of atmospheric concentrations of reduced greenhouse gases like methane and ammonia as well as the increase in atmospheric oxygen. Oxygen itself is not a greenhouse gas, but the possible influence of enhanced pressure broadening on the atmospheric greenhouse has been examined by François and Gérard (1988). In addition, the rise of oxygen should have led to the rise of its photochemical product, ozone, which is a greenhouse gas. Ozone 
densities in possible primitive atmospheres have been studied theoretically by a number of authors (Ratner and Walker, 1972; Levine et al., 1979; Kasting and Donahue, 1980; Levine, 1985; François and Gérard, 1988). It is necessary, in theoretical studies of the photochemistry of the Precambrian atmosphere, to consider the influence of enhanced ultraviolet fluxes from the young sun (Zahnle and Walker, 1982; Canuto et al., 1982). Direct climatic consequences of the enhanced ultraviolet fluxes are likely to have been small, although stratospheric temperatures may have been affected by these enhanced fluxes as well as by the rise of atmospheric ozone.

\section{Minor greenhouse gases}

The original suggestion of Sagan and Mullen (1972) concerning the greenhouse solution to the problem of the faint young sun concerned reduced greenhouse gases like methane and ammonia. Subsequent studies using detailed models of atmospheric photochemistry suggest that the concentrations of these reduced gases would have been too low to influence the atmospheric greenhouse significantly (Kuhn and Atreya, 1979; Kasting, 1982; Kasting et al., 1983; Levine, 1985; Zahnle, 1986). Both of these gases are rapidly destroyed in atmospheres containing water, carbon dioxide, and sunlight. The presence of free oxygen is not necessary. In addition, ammonia dissolves readily in the ocean.

\section{Cloud cover}

Of all the factors that might have an important effect on the Precambrian climate the most uncertain is probably cloud cover. Clouds have an important effect on the radiation balance of the atmosphere, influencing both the absorption of short-wave solar radiation and the emission of long-wave planetary radiation (Ramanathan et al., 1989). The effect depends on cloud thickness and height. Low altitude clouds tend to cool the planet because they reflect away sunlight while radiating to space at relatively warm temperatures. Conversely, high altitude clouds tend to warm the planet by shielding the warm surface and lower atmo- sphere and radiating to space at relatively low temperatures. The potential importance of changing cloud cover to the Precambrian climate has been convincingly demonstrated by Henderson-Sellers and colleagues (Henderson-Sellers, 1979; Henderson-Sellers and Cogley, 1982; Cogley and Henderson-Sellers, 1984; HendersonSellers and Henderson-Sellers, 1988).

A pioneering study of cloud feedback and its possible influence on the Precambrian climate has been published by Rossow et al. (1982). The work used a one-dimensional radiative convective calculation of the temperature profile in the atmosphere with explicit treatment of clouds. The model predicted that cloud feedbacks could do much to ameliorate the problem of reduced solar luminosity early in Earth history. More study of the factors that control clouds and their climatic influence is needed.

Interestingly, while the influence of clouds is potentially so large, and is so poorly quantified, the much discussed role of surface ice now seems of little importance. The so called ice-albedo catastrophe was a prominent feature of early energy balance climate models (Budyko, 1969; Sellers, 1969; North, 1975; North et al., 1981). In these models it was assumed that ice of high albedo formed where annual average temperature fell below a critical value. A relatively modest reduction in solar luminosity caused the planet to cool, the ice edge to advance to lower latitudes, and the planetary albedo to increase, with a positive feedback that made the theoretical climate system very sensitive to reductions in solar luminosity. The problem is much less severe in energy balance climate models that incorporate a more careful treatment of albedo. Such a model has been presented and studied by Kuhn et al. (1989). These authors find that global average temperature is relatively insensitive to the presence of ice at high latitudes because the albedo is already large at high latitudes even without ice (Henderson-Sellers and Meadows, 1979). The albedo is large at high latitudes because of extensive cloud cover, and because the albedo of Earth and atmosphere increases strongly with increasing solar zenith angle. After a proper allowance for the effects of 
cloud cover and atmospheric scattering, it turns out that ice on the ground does not have much effect on albedo. The albedo formulation of Kuhn et al. (1989) is based on spacecraft observations of average albedo as a function of latitude and temperature. The model does exhibit ice-albedo feedback, but it is much less sensitive to the effect than the models of North (1975) and Budyko (1969). Recent exploratory work with a seasonal energy balance climate model shows that global average temperature is insensitive to high latitude ice even with allowance for the effect of long polar days and nights.

The same insensitivity of the climate system to high latitude ice has been reported by Hunt (1984) from a study using a general circulation model. It therefore seems unlikely that Precambrian climates would have depended critically on the presence or absence of high latitude ice or on the presence or absence of high latitude land on which permanent ice caps could form.

\section{Carbon dioxide}

For many people, the preferred solution to the problem of the cool young sun is a greatly enhanced carbon dioxide greenhouse effect. This solution to the problem was first suggested by Owen et al. (1979) who calculated that enhancement of the carbon dioxide concentration in the atmosphere by a factor of about 1000 would be sufficient to keep the Earth from freezing over even with solar luminosity reduced by $25 \%$. With some difference in emphasis and detail, similar conclusions have since been reached by Walker et al. (1981), Kuhn and Kasting (1983), Kasting and Pollack (1984), Kasting and Ackerman (1986), Kasting (1988), and Kuhn et al. (1989). These calculations have used either one-dimensional radiative-convective models of atmospheric temperatures or energy balance climate models with radiation parameters derived from one-dimensional radiative-convective calculations. I do not know of any published study of the consequences of large carbon dioxide enhancements that has used a general circulation model.
As a word of caution, it should be noted that conclusions about the greenhouse effect of enhanced carbon dioxide concentrations generally depend on an assumption about water vapor. The greenhouse effect of water vapor is much larger than the greenhouse effect of carbon dioxide, but the water vapor content of the atmosphere clearly depends on temperature, so it is not an independent variable. A conservative assumption is probably one of constant relative humidity. With this assumption, the effect of the water vapor greenhouse is to approximately double the temperature change caused by some other perturbation, for example a perturbation in the amount of carbon dioxide in the atmosphere. If absolute humidity rather than relative humidity were held constant, therefore, the temperature increase caused by an increase in carbon dioxide concentration would be approximately halved. Predictions about the thermal consequences of large carbon dioxide concentrations in the Precambrian atmosphere are therefore subject to uncertainty related to the water vapor content of the atmosphere. Compared with other uncertainties this is probably not a major concern; relative humidity cannot exceed unity by any significant amount; if it were much less than unity precipitation would stop and water would accumulate in the atmosphere. It seems unlikely that average relative humidity can have been very different from its present day value of about one-half.

Another uncertainty less commonly recognized concerns the temperature profile in the atmosphere. We may think of the greenhouse effect as arising because the planet radiates to space from the top of the atmosphere in regions of the spectrum where the atmosphere is opaque (Henderson-Sellers, 1978). Because the top of the atmosphere is colder than the surface the system adjusts to a higher temperature to balance incoming and outgoing radiation. Therefore, the greenhouse effect caused by a given increment in atmospheric opacity depends on the temperature at the top of the atmosphere. This temperature is calculated in radiative-convective models, which yield results reasonably close to those of the present day atmosphere. 
Because of simplifications in the way these models treat atmospheric motions, water vapor distribution, clouds, and other complications of the real world it is not obvious that they will correctly describe high altitude temperatures under the very different conditions of the Precambrian Earth.

What grounds are there for believing that the carbon dioxide partial pressure was very large in the Precambrian? Some evidence can be deduced from the state of weathering of ancient soil profiles (Holland, 1984; Grandstaff et al., 1986; Retallack, 1986). Studies published so far probably do not support the very high partial pressures favored on climatic grounds, but the interpretation of the paleosol evidence is certainly not straightforward. The paleosol evidence is promising but not yet persuasive. A potential source of information is provided by carbon isotope data. The fractionation between oxidized carbon and reduced carbon in sediments increases with increasing carbon dioxide pressure (Dean et al., 1986; Popp et al., 1989; Rau et al., 1989). This paleobarometer has not yet been calibrated, and there will be many uncertainties in applying it to very ancient sediments containing carbon deposited by poorly characterized microbes, but the potential for data on ancient carbon dioxide amounts is there (Schidlowski et al., 1983). For the time being, the case for high carbon dioxide amounts in the early atmosphere rests largely on theoretical arguments.

An initial look at the problem was taken by Walker (1983). This investigation was undertaken largely to counteract ideas then current that large carbon dioxide partial pressures on the early Earth would have caused the ocean either to fizz like soda pop or to be excessively corrosive, or both. Walker pointed out that the $\mathrm{pH}$ of sea water depends not only on the carbon dioxide partial pressure but also on the alkalinity. The paper showed that high carbon dioxide partial pressures were not inconsistent with an ocean saturated with respect to calcium carbonate and could not be ruled out by present knowledge of the sedimentary rock record.

The first prediction of the early history of atmospheric carbon dioxide based on serious consideration of the controlling processes was by Walker et al. (1981). These authors argued that the critical feedback occurred via the process of weathering of silicate minerals, which releases calcium and other ions that can combine to form carbonate sediments with the carbon dioxide released by volcanic and metamorphic processes. It was argued that the rate of this weathering process depends on temperature, both directly and through the influence of temperature on the hydrologic cycle. If, for example, solar luminosity increases, planetary average temperature increases, the rate of weathering increases, carbon dioxide is reduced, the carbon dioxide greenhouse effect is reduced, and the planet cools as a result. The geochemical cycle of carbon dioxide therefore provides a negative feedback in the climate system that buffers surface temperature against changes in solar luminosity. Walker et al. (1981) argued that this negative feedback mechanism would have kept Earth warm by yielding greatly enhanced carbon dioxide amounts early in planetary history, when solar luminosity was small.

The deduction of large carbon dioxide pressures was strengthened by Lovelock and Whitfield (1982), who called attention to the possible enhancement of weathering rates caused by land plants. The carbon dioxide pressure in soil gas today is enhanced by one or two orders of magnitude relative to the atmosphere (Holland, 1978) as a result of root respiration and decay. From this observation it is argued that plants significantly increase the rate of silicate weathering and therefore the rate of consumption of atmospheric carbon dioxide (Knoll and James, 1987; Volk, 1987, 1989). In my view, the situation is not entirely clear. It is not clear that the promotion of chemical attack by plants can compensate for the inhibition of physical denudation. Most fresh, unweathered rock today is deeply buried beneath a blanket of soil maintained by plants. Would this fresh rock be dissolving more or less rapidly if the plants were not there? The work of Meybeck $(1979,1987)$ shows clearly that weathering rates increase with temperature and runoff, but whether this increase is en- 
hanced or diminished by the flourishing vegetation of the tropics is not apparent from the data. Meybeck's work shows also that silicate weathering rates are larger in mountainous areas than in low lying areas, which may be evidence of the important stabilizing role of a soil blanket (Pinet and Souriau, 1988).

Weathering rates on the Precambrian Earth may well have been significantly affected by the absence of vascular plants and the probable sparsity of presumed nonvascular terrestrial vegetation, but it is far from clear whether they would have been increased or decreased. Our attempts to imagine the Proterozoic land surface are further confused by the fact that large areas in the Northern Hemisphere were recently scraped free of soil by the Pleistocene glaciations. Our familiar world may therefore be deficient compared with the long-term geological average in deeply weathered and chemically unreactive regolith.

Notwithstanding these unresolved questions, the obvious defect of the mechanism proposed by Walker et al. (1981) is that it does not apply to a world without continents. The geochemical cycle explored by Walker et al. balances volcanic and metamorphic release of carbon dioxide against consumption of carbon dioxide by terrestrial weathering of silicate minerals. This is the mechanism believed to operate on the modern world. It is a mechanism that may well have worked also in the Proterozoic after extensive areas of land were exposed to weathering. But it would not have worked on a world without significant areas of exposed land surface, such as may well have existed prior to perhaps $3 \times 10^{9}$ yr ago.

An attempt to estimate carbon dioxide partial pressures on a world without continents was made by Walker (1985), who concluded that carbon dioxide pressures as large as 10 bars might have been present in the early atmosphere. Walker's argument was based on consideration of total masses of carbon rather than the previous arguments based on fluxes. Today, most of the carbon at the surface of the Earth is stored as sedimentary carbonate rocks on stable continental platforms. Walker assumed that all of this carbon was released from the interior of the Earth essentially at the time of Earth accretion. If there were no stable continental platforms when the Earth was young, the carbon could not have been stored in long-lived rock reservoirs. Instead, it must have been in ocean and atmosphere or in the form of ephemeral carbonate deposits on short-lived sea floor. I now believe that this argument does not apply. The problem lies in the assumption that the total amount of carbon at the surface of the Earth has remained constant since early Earth history. This position can no longer be sustained in the face of overwhelming evidence for large fluxes of carbon from the mantle to the ocean associated with mid-ocean ridge hydrothermal systems (Des Marais, 1985). Present day mantle fluxes of carbon dioxide are large enough to supply all of the carbonate rocks present on the surface of the Earth in a time of $5 \times 10^{9} \mathrm{yr}$ or so. This observation does not imply that carbon is presently accumulating at the surface of the Earth because there may be equally large return fluxes from surface to mantle associated with the subduction of carbonate sediments and weathered sea floor (Sibley and Vogel, 1976; Javoy et al., 1982; Walker, 1983).

The free exchange of carbon between the mantle and the exogenic system is convincingly demonstrated by a comparison of data for carbon dioxide and for ${ }^{36} \mathrm{Ar}$ (Marty and Jambon, 1987). The flux of carbon dioxide from mantle to atmosphere today is $2 \times 10^{12} \mathrm{~mole} / \mathrm{yr}$ (Fig. 3). The flux of ${ }^{36} \mathrm{Ar}$ is $250 \mathrm{~mole} / \mathrm{yr}$, so the ratio of the fluxes is $8 \times 10^{9}$ via mid-ocean ridge hydrothermal systems (Des Marais, 1985). On the other hand, the ratio of the amounts in atmosphere, ocean, and continental crust is $1.8 \times 10^{6}$. The ratio of fluxes is very much larger than the ratio of amounts now present in the surface layers of the Earth. Carbon is missing from the surface layers relative to argon.

This conclusion can be seen also in the accumulation times calculated by dividing the flux into the amount. Carbon would accumulate at present rates in $5 \times 10^{9} \mathrm{yr}$, but it would take $2.2 \times 10^{13}$ yr for the ${ }^{36} \mathrm{Ar}$ now in the atmosphere to accumulate at the present flux. The conclu- 


\section{Accumulation times: $5 E 9 \quad 2.2 \mathrm{E} 13 \mathrm{y}$ AMOUNT/FLUX \\ Amounts: $\begin{array}{ll}1 \mathrm{E} 22 \\ \text { Ratio } \mathrm{C} / \mathrm{Ar}= & 5.6 \mathrm{E} 15 \text { mole } \\ 1.8 \mathrm{E} 6\end{array}$}

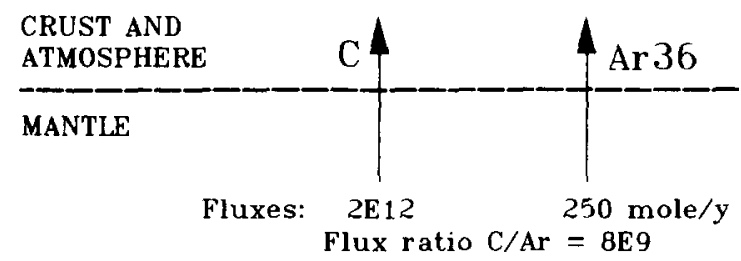

Fig. 3. Fluxes of carbon and ${ }^{36} \mathrm{Ar}$ from mantle to atmosphere compared with the amounts of these elements in the exogenic system.

sion is that while ${ }^{36} \mathrm{Ar}$ was massively degassed early in Earth history, carbon did not participate in this early degassing. If carbon were rapidly released from the mantle early in Earth history it was just as rapidly returned to the mantle.

Carrying this analysis further, it can be concluded that carbon is a lithophile and not an atmophile element (Berg, 1986). From the flux ratio of carbon to ${ }^{36} \mathrm{Ar}$ and the concentration of ${ }^{36} \mathrm{Ar}$ in the upper mantle (Allegre et al., 1987) I can calculate the concentration of carbon in the upper mantle. The value is $1 \times 10^{-4} \mathrm{~mole} / \mathrm{g}$. This calculation assumes that carbon is not more mobile than argon, surely a reasonable assumption. From the concentration and the mass of the upper mantle (Allegre et al., 1987) I calculate that there are $1.4 \times 10^{23}$ moles of carbon in the upper mantle. The amount in the crust and atmosphere and ocean is only $1 \times 10^{22}$ moles (Wilkinson and Walker, 1989). Therefore, less than $10 \%$ of upper mantle carbon has been degassed (Tingle and Green, 1987). By way of contrast, more than $99 \%$ of upper mantle ${ }^{36} \mathrm{Ar}$ has been degassed. It seems that the fate of most carbon dioxide released from the mantle was to be incorporated into oceanic crust in weathering reactions and to be carried back into the mantle on subduction. Only a small fraction of the carbon has been captured in the exogenic system as cratonic carbonate rocks.

Because of these deficiencies in previous theoretical studies of carbon dioxide in the Archean atmosphere I shall present, in the remaining sections of this paper, a new examination of the evolution of the geochemical cycles of carbon.

\section{Evolution of the geochemical cycles of carbon}

In this section I plan to explore the nature of the geochemical cycles of carbon on a world without continents and to conduct a preliminary study of the transition from such a hypothetical world to a world more like that of the present day. There has not been much previous work on this subject and there is little reliable information. My study will depend heavily on guesswork and will be speculative. While some of my guesses and speculations will probably be wrong, I hope to provide a point of departure for future examination of these aspects of Earth history. I hope that my study will bring into focus the issues that require more theoretical or observational attention and will raise questions for which answers can soon be found.

I will present my findings in the form of a quantitative model of evolving geochemical cycles. The quantitative model cannot provide reliable, quantitative predictions of the history of atmospheric carbon dioxide. The uncertainties in processes, rates, and dates are at present too great for such quantitative confidence. The virtue of a computational model, even a highly speculative one, is that it rigorously requires at least internal consistency. The computation will quickly call attention to formulations or assumptions that are erroneous in its own mathematical world. A theory that is internally consistent and complete is certainly a necessary step along the path to a theory that describes what really happened on the Earth.

My simulation of the geochemical cycles of carbon on the Precambrian Earth is derived from a simulation of the cycles of carbon today. The modern cycles have been described by Broecker (1971), Holland (1978), Walker (1977), Broecker and Peng (1982), Berner et al. (1983), and Walker and Drever (1988). Carbon dioxide is released from the solid phase to ocean and atmosphere by volcanic and metamorphic 
processes (Fig. 4). It is returned to the solid phase as calcium and magnesium carbonate minerals and also as reduced carbon of biological origin. The extraction of carbon from the fluid phase by precipitation of carbonate minerals requires a corresponding supply of calcium and magnesium ions. These ions are supplied by the weathering and dissolution of silicate minerals at a rate that presumably depends at least in part on the carbon dioxide content of the atmosphere. The dissolution of carbonate minerals of limestones and dolomites cannot serve as this source of calcium and magnesium ions because dissolution of carbonates releases carbon at the same rate as it releases cations, and this carbon must be removed from the fluid phase by the precipitation of carbonate minerals. In the present system, therefore, the partial pressure of atmospheric carbon dioxide adjusts to provide a rate of silicate dissolution just big enough to match the rate of volcanic and metamorphic supply of carbon dioxide. At the same time, the saturation state of the ocean with respect to calcium carbonate adjusts so that calcium carbonate minerals are precipitated as fast as the needed cations are provided by dissolution of carbonate minerals and by dissolution of silicate minerals.

On the present Earth the precipitation of calcium carbonate minerals from the ocean is mediated by carbonate-secreting plankton and

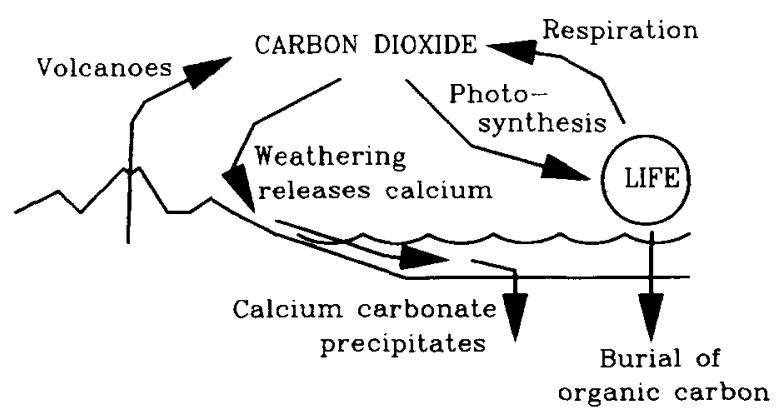

Fig. 4. Atmospheric carbon dioxide is controlled by the balance between metamorphic and volcanic release of the gas from the solid phase and the weathering of silicate minerals which releases calcium ions to solution, causing calcium carbonate minerals to precipitate. Carbon dioxide is affected also by biological reduction and oxidation.

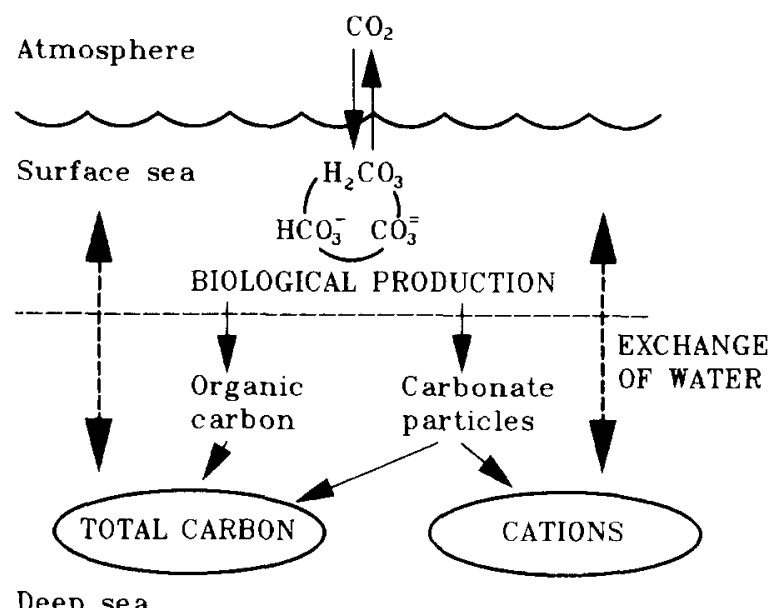

Fig. 5. Atmospheric carbon dioxide approaches equilibrium with dissolved carbon species in the surface ocean. The surface ocean exchanges dissolved carbon and net positive charge (equals minus alkalinity) with the deep ocean as a result of settling of biogenic particles and mixing of surface water with deep water.

depends on the saturation state of the deep sea (Fig. 5). Plankton in the surface layers of the ocean, exposed to sunlight, send a rain of particles of both organic material and calcium carbonate shells into the deep ocean. The organic matter is largely oxidized; the shells dissolve if they fall into unsaturated water or accumulate as deep sea carbonate sediments if they fall to the bottom in water saturated with respect to calcium carbonate. The saturation state of sea water depends on the concentration of carbonate ions, $\mathrm{CO}_{3}^{2-}$, and thus on the balance between the different dissolved carbon species. The species depend on total dissolved carbon and the requirement that the solution be electrically neutral, that there be as many negative charges per unit volume as positive charges. The total concentration of charge carried by the carbon species is called the alkalinity (strictly the carbonate alkalinity). Because the solution must be electrically neutral overall, the alkalinity equals the negative of the total concentration of charge carried by all ions other than bicarbonate and carbonate. Alkalinity is therefore determined by the species other than carbon dissolved in the water. For a given concentration of 
total dissolved carbon, the proportions as doubly-charged carbonate and singly-charged bicarbonate ions adjust to yield the required alkalinity (Broecker and Peng, 1982).

The rain of particulate carbon into the deep sea increases the concentration of total carbon there, resulting in lower carbonate ion concentration and waters that are more corrosive to calcium carbonate. The rain of particles of shell material carries both carbon and positive charge (in the form of calcium ions) into the deep sea. The equivalent flux of alkalinity tends to increase the carbonate concentration in deep sea water and to make it less corrosive to calcium carbonate. The downward fluxes of carbon and alkalinity in particulate form are balanced by upward fluxes of dissolved carbon and alkalinity transferred by the mixing of deep sea water with enhanced concentrations of carbon and alkalinity with surface sea water having reduced concentrations of alkalinity and total carbon.

In equilibrium the partial pressure of atmospheric carbon dioxide depends on the alkalinity of surface sea water and the total dissolved carbon concentration in surface sea water. If carbon dioxide is added to the system of ocean and atmosphere, by volcanic processes for example, the ocean becomes more acidic, the rate of precipitation of carbonate sediments decreases and the rate of dissolution of terrestrial carbonate and silicate minerals increases. The result is an increase of the alkalinity of sea water that neutralizes the added carbon dioxide, increases the proportion of the sea floor bathed in supersaturated water, and gradually restores the system to equilibrium by extracting the added carbon dioxide in the form of new sea floor sediments.

The oxidation and reduction of carbon also play a role. Biological photosynthesis extracts carbon dioxide from ocean and atmosphere and releases oxygen. Most of this oxygen is consumed in processes of respiration and decay, which restore carbon dioxide to atmosphere and ocean. Some of the organic carbon produced by photosynthesis does not undergo immediate respiration and decay. Instead it is preserved in sediments, principally on the continental shelves and slopes (Berner, 1982), to become a constituent of a long-lived geological reservoir of reduced organic carbon or kerogen. The oxygen left behind when this organic carbon is incorporated into sediments reacts in due course with ancient sedimentary kerogen exposed to the atmosphere by processes of erosion and weathering. The oxygen content of the atmosphere is believed to be controlled by these processes of burial of newly synthesized organic carbon in sediments and oxidation of ancient sedimentary kerogen (Holland, 1973; Walker, 1974, 1977, 1980; Berner and Canfield, 1989). The burial rate presumably decreases and the oxidation rate might in principle increase as the partial pressure of atmospheric oxygen increases. In the long term, presumably, kerogen is oxidized as fast as new carbon is buried, so the impact of the oxidation-reduction cycle on the carbon cycle is minimized. It is possible to imagine periods of imbalance, however, in which for example excess organic carbon is buried, causing a temporary decrease in atmospheric carbon dioxide and a permanent increase in atmospheric oxygen. Some evidence for such episodes in Earth history has been reported in the form of times of unusually heavy carbon isotopes preserved in carbonate minerals (Popp et al., 1986; Goodfellow, 1986; Knoll et al., 1986; Magaritz et al., 1986; Aharon et al., 1987; Lambert et al., 1987; Arthur et al., 1988; Baker and Fallick, 1989a, b).

The interactions described here can be incorporated into a computational model which can be tuned to reproduce the observed properties of the present ocean and atmosphere. Such a model can then be run forward in time to study, for example, the fate of fossil fuel carbon dioxide (Kasting and Walker, 1990), or it can be used to study environmental changes in recent geological history (Berner et al., 1983; Lasaga et al., 1985; Marshall et al., 1988; Walker, 1989, 1990a). The model must be adapted before it can be applied to more remote periods of geological history. For one thing, the global weathering rate must be related to the area of dry land exposed to weathering. This relationship is usually assumed to be first order. A more subtle interaction between the carbon geochemical 
cycles and climate has been investigated by Marshall et al. (1988). These authors note the clear evidence that low latitude continents in warm wet climates weather much faster than high latitude continents in cold dry climates. Exploring the consequences of this dependence, they find that carbon dioxide partial pressure would tend to be low and the climate cool when continental drift led to a concentration of land area in the tropics. Conversely, concentration of land area at high latitudes would tend to result in high carbon dioxide partial pressure and warm climate.

The first major change as we move back in time is the removal of carbonate-secreting plankton. The first record of these organisms dates back about 175 million years. There is no evidence for the precipitation of deep sea carbonate sediments in the Paleozoic. Carbonate sedimentation appears to have been largely restricted to shallow water continental shelves in the Paleozoic and probably also in the Precambrian, although today only about $10 \%$ of carbonate precipitation occurs in shallow waters (Wilkinson and Walker, 1989). Shallow water carbonate precipitation was a consequence of the biological activities of benthic, reef-forming organisms. It presumably was influenced by the saturation of shallow sea water with respect to calcium carbonate, in contrast to the present system where the rate of carbonate accumulation is controlled by the saturation state of deep sea water (B. Opdyke, pers. comm. 1989). In the early Paleozoic the system was presumably further modified by the absence of vascular plants on land and the consequent changes in weathering rates discussed above.

In the calculations to be described below I shall take as one limit a Proterozoic world in which continental land area was not very different from the present day, but there were no land plants. There was a vigorous and productive benthic biota occupying shallow waters on the continental shelves but there were no plankton. The oxidation-reduction cycle was essentially modern, with burial of organic carbon on the continental shelves balanced by oxidation of ancient sedimentary kerogen. The carbon cycle was essentially modern, with the release of carbon dioxide from the mantle at mid-ocean ridge hydrothermal systems and by the metamorphic decarbonation of carbonate sediments balanced by the weathering of silicate minerals and the precipitation of carbonate sediments on the continental shelves. The climatic calculations of Kasting (1987b) suggest that a partial pressure of carbon dioxide 100 times that of the present would have been needed to keep the Earth warm when the sun was less luminous. I shall adopt this carbon dioxide pressure as a tuning target for the simulation. The higher carbon dioxide pressure is attributed in part to increased volcanic and metamorphic release of carbon dioxide when the heat flow from the interior of the Earth was larger (Pollack, 1980; Hargraves, 1986) and in part to lower weathering rates, possibly a consequence of smaller land area, possibly a consequence of a somewhat cooler globe, or possibly a consequence of the absence of vascular plants.

I want to compare this Proterozoic world with a hypothetical Archean world in which there was little dry land, little area of stable continental shelf and correspondingly little biological production of oxygen, organic carbon, or biogenic carbonate minerals. The masses of sedimentary carbonates and sedimentary kerogen were small by reason of the small area of stable continental platforms and the low level of biological activity. There was little free oxygen in ocean and atmosphere. The biological oxidation-reduction cycle involved the oxidation of dissolved ferrous iron to particulate ferric iron when carbon dioxide underwent photosynthetic reduction and the corresponding reduction of ferric iron to ferrous iron in biological energyproducing processes of anaerobic respiration (Froelich et al., 1979; Walker, 1984, 1987; Wilson et al., 1986; Daniels et al., 1987; Frankel, 1987; Lovley et al., 1987). According to Kasting's climatic calculations the carbon dioxide partial pressure at this time, perhaps 3 billion years ago, might have been as high as 1000 times the present value, the high value resulting from the absence of terrestrial weathering as a sink for volcanic and metamorphic carbon dioxide. 
The goal of the numerical simulation is to reproduce these proposed worlds and to provide a smooth and plausible transition between them. In its essence, the transition is between a presumed Archean world with little land, few sediments, and sparse life and a presumed Proterozoic world with much land, many sediments, and abundant life. I shall assume that the changes in these global properties occurred at the same time, in accordance with Knoll's (1979) suggestion that increasing biological activity was made possible by increasing area of stable, shallowwater, shelf environments. Other possible histories can be imagined, and as noted before, it is not agreed by all concerned that the Archean world was impoverished in land area, sedimentary mass, and biological productivity.

\section{Numerical simulation}

The goal is to simulate the transition from an essentially abiological world with chemistry dominated by sea floor interactions to a biologically active world dominated by continental interactions on land and on the continental shelves. In what follows I shall discuss the interactions that are important in the Proterozoic separately from the interactions important in the Archean, but the simulation includes all of these interactions together. Details of the calculation appear in the appendix.

The transition is driven by an increase in relative land area from a value of $10^{-4}$ in the Archean to a value of 1 in the Proterozoic. In this simulation I assume that the transition occurs as a linear function of time over a span of $500 \times 10^{6} \mathrm{yr}$ (Eriksson and Donaldson, 1986). I assume that the area of shallow water on the continental shelves is proportional to the land area and that biological productivity is also proportional to land area. As a precaution, to ensure that biological production does not suck all of the carbon out of the ocean and atmosphere, the productivity function includes the factor $\mathrm{PCO} 2 \mathrm{~S} /(1+\mathrm{PCO} 2 \mathrm{~S})$, where PCO2S is the partial pressure of carbon dioxide in equilibrium with surface sea water. This function is constant for PCO2S much greater than 1 and goes to zero as $\mathrm{PCO} 2 \mathrm{~S}$ goes to zero, corresponding to a carbon limit on productivity at low carbon dioxide partial pressures. This precautionary factor has no influence on the present calculations because PCO2S is always much greater than 1.

The calculation distinguishes between the shallow ocean with a volume of $0.12 \times 10^{18} \mathrm{~m}^{3}$ and the deep ocean with a volume of $1.23 \times 10^{18}$ $\mathrm{m}^{3}$. These volumes are the modern values (Broecker and Peng, 1982). The water flux between reservoirs is $0.001 \times 10^{18} \mathrm{~m}^{3} / \mathrm{yr}$. This flux exchanges dissolved constituents between the deep and shallow ocean reservoirs. The redox calculation lumps atmospheric gases with dissolved gases in the surface ocean reservoir, effectively assuming equilibrium between atmosphere and surface ocean. For the carbon cycle calculation it is more convenient to separate dissolved carbon in the surface ocean from atmospheric carbon dioxide. The calculation follows the time evolution of 15 chemical reservoirs, tabulated in the Appendix. These are oxygen in the atmosphere and dissolved in the surface ocean, oxygen dissolved in the deep ocean, reactive organic carbon on the continental shelves, reactive oxidized iron, reduced iron dissolved in the surface ocean, reduced iron dissolved in the deep ocean, reduced gases in the atmosphere and dissolved in the surface ocean, reduced gases dissolved in the deep ocean, old sedimentary kerogen, total carbon dissolved in the surface ocean, total carbon dissolved in the deep ocean, alkalinity in the surface ocean, alkalinity in the deep ocean, atmospheric carbon dioxide, and ancient sedimentary carbonates. Except where there is reason to assume a different rate law I have taken all reaction rates to be first order in the reacting species.

Biological production, already discussed, adds oxygen to atmosphere and surface ocean and reactive organic carbon on the continental shelves. In the Proterozoic world the oxygen and organic carbon largely react with one another again, at a rate proportional to the products of organic carbon amount and oxygen concentration. Biological production extracts carbon from the surface ocean reservoir and the respiration 
reaction between oxygen and organic carbon restores dissolved carbon to that reservoir. A small fraction of the reactive organic carbon escapes immediate oxidation to become incorporated in the sedimentary kerogen reservoir. The burial rate law is first order in the mass of reactive organic carbon. Sedimentary kerogen is consumed mainly by weathering oxidation at a rate proportional to the atmospheric oxygen amount and the size of the sedimentary kerogen reservoir. This weathering reaction consumes atmospheric oxygen and adds carbon dioxide to the surface ocean. A fraction of the sedimentary kerogen is destroyed by volcanic and metamorphic processes, which oxidize carbon while reducing ferric iron, adding carbon dioxide to the atmosphere but not directly affecting atmospheric oxygen.

Carbonate precipitation takes place on the continental shelves at a rate proportional to the product of biological productivity and the concentration of dissolved carbonate ions in surface sea water, a concentration that represents the saturation state of the sea water with respect to calcium carbonate. The speciation of dissolved carbon between aqueous carbon dioxide, bicarbonate ions, and carbon ions is calculated from alkalinity and total dissolved carbon using the standard equations that describe thermodynamic equilibrium in the carbonate system (Broecker and Peng, 1982). Precipitation of calcium carbonate extracts total carbon and alkalinity from the surface ocean reservoir and adds calcium carbonate to a reservoir of carbonate sediments on the continents. Sedimentary carbonates are consumed by carbonate weathering at a rate proportional to the masses of sedimentary carbonates and to the carbon dioxide partial pressure raised to the power of 0.3 (Walker et al., 1981). Carbonate weathering adds carbon and alkalinity to the surface ocean reservoir. A constant fraction of the sedimentary carbonate is consumed by volcanic and metamorphic processes (metamorphism of platform carbonates during orogenies), which add carbon dioxide to the atmosphere but are not a source of alkalinity. The rate of silicate weathering is proportional to land area and the carbon dioxide

\section{CARBON EXCHANGE IN THE PROTEROZOIC}

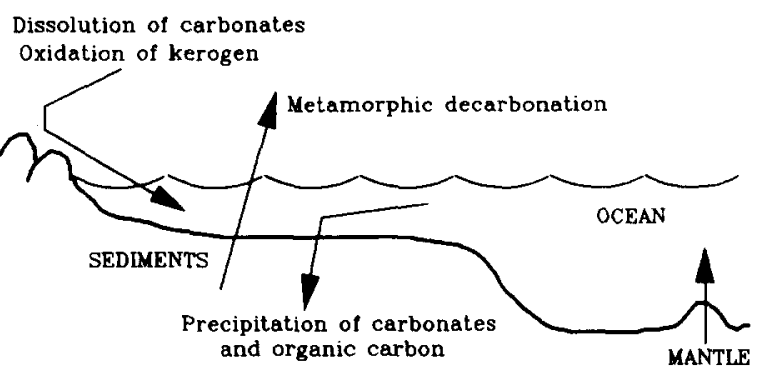

Fig. 6. Carbon exchange in the Proterozoic. The simulation balances the rate of release of carbon dioxide from the mantle and from sediments by metamorphic decarbonation, by dissolution of carbonates, and by oxidation of kerogen, against the rate of precipitation in new sediments of carbonate minerals and organic carbon.

partial pressure raised to the power of 0.3 . Silicate weathering contributes alkalinity to the surface ocean, but is not a source of total carbon.

In addition to the volcanic source of carbon dioxide that is proportional to the masses of sedimentary carbonate and sedimentary kerogen there is a fixed mid-ocean ridge source of mantle carbon dioxide, which is held constant at $5 \times 10^{12}$ mole/yr, somewhat larger than the present value (Des Marais, 1985). This source adds total carbon to the deep ocean reservoir (Fig. 6). This flux constitutes a transfer of carbon from the mantle to the exogenic system. In the Proterozoic world, as simulated here, without plankton to generate abundant carbonate sediments on the deep sea floor, there is no mechanism for a correspondingly large flow of carbon from the exogenic system back to the mantle. Therefore, in this simulation carbon continues to accumulate in the reservoir of continental carbonate sediments even after the transition from Archean to Proterozoic conditions is complete. Such a secular increase in the mass of the sedimentary carbonate reservoir may indeed have occurred during the course of Earth history as a result of the release of carbon dioxide from the mantle, possibly coming to an end just in the last 100 million years as a result of the origin of carbonate-secreting plankton. Alternatively, perhaps the simulation should include more rapid incorporation of carbon into the sea floor by low temperature weathering processes or a 
smaller flux of carbon out of the mantle in mid-ocean ridge hydrothermal systems.

All of the other parameters and rate coefficients in the calculation are adjusted to yield concentrations and reservoir amounts that seem to me reasonably close to those of the present day, except that the carbon dioxide pressure in the atmosphere is enhanced by a factor of about 100. Similarly, the parameters and rate coefficients that relate to the Archean world are adjusted to yield what might be reasonable Archean values in a steady state that is achieved before land area and therefore biological productivity begin to increase. The reservoirs of sedimentary kerogen and carbonate have very long lifetimes and are not brought to steady state in the Archean. Instead, they are assumed to be negligibly small, under the assumption that significant biological activity has not been going on for long. The carbon isotope record (Schidlowski, 1988) provides evidence concerning the partitioning of carbon flux between oxidized and reduced forms, but not the magnitude of the flux or the magnitude of the reduced carbon reservoir.

The Archean world lacks the sink for carbon provided by biological precipitation of carbonates and organic carbon on the continental shelves. If the carbon released from the mantle at mid-ocean ridge hydrothermal systems is not to accumulate without limit in ocean and atmosphere there must be an alternative sink (Fig. 7). I have assumed that this alternative sink is provided by low temperature weathering of the

\section{CARBON AND ALKALINITY IN THE ARCHEAN}

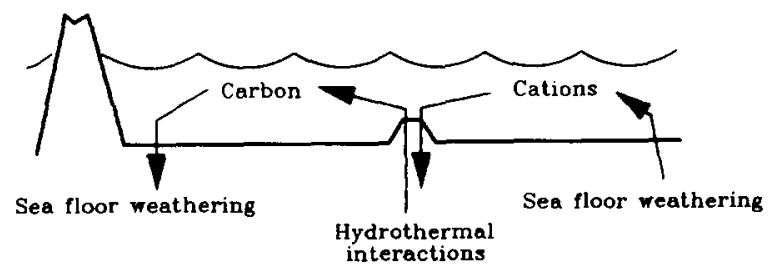

Fig. 7. Carbon and alkalinity in the Archean. On a world without continents or abundant life, the simulation balances the hydrothermal release of carbon against its consumption in sea floor weathering reactions and the release of alkalinity in sea floor weathering reactions against its consumption in hydrothermal interactions. sea floor (Staudigel and Hart, 1983), a process that might be responsible for the pervasive carbonation of submarine basalts reported to be a feature of the Archean (Roberts, 1987). I have arbitrarily assumed that this sea floor weathering process removes carbon from the deep sea reservoir at a rate proportional to the total dissolved carbon concentration in the deep ocean. The proportionality constant I have taken to be in turn proportional to the hydrogen ion concentration in deep sea water. The picture I have of the weathering process is that hydrogen ions in sea water attack sea floor basalt, releasing calcium ions which then react with dissolved carbon in the sea water to precipitate calcium carbonate minerals within the sea floor.

The alkalinity budget of the ocean similarly requires reanalysis for the Archean world since the continental source of cations is absent as is the biological sink. I assume that the same low temperature sea floor weathering process that consumes carbon releases cations to the deep ocean reservoir at a rate proportional to the hydrogen ion concentration in sea water. The process I imagine is the conversion of feldspars to clay minerals. The sink for positive charge is assumed to be hydrothermal interaction with the sea floor at high temperatures, mainly the depletion of dissolved magnesium in hydrothermal waters. I assume that the rate of removal of alkalinity from the deep sea reservoir is proportional to the alkalinity. This treatment of the alkalinity budget of the Archean ocean is wildly speculative. At this stage I hope mainly to call attention to the fact that the alkalinity budget would be very different on a world without continents and without much biological activity and to endorse the ideas of Veizer et al. (1982, $1989 a, b)$ and others that sea water composition was controlled mainly by interactions with the sea floor.

While the carbon cycle in this hypothetical Archean world is speculative but simple, the oxidation-reduction cycle is speculative and complex (Fig. 8). The system describes the first order reactions between oxygen and oxidized iron on the one hand and organic carbon, reduced iron, and reduced gases like hydrogen and 


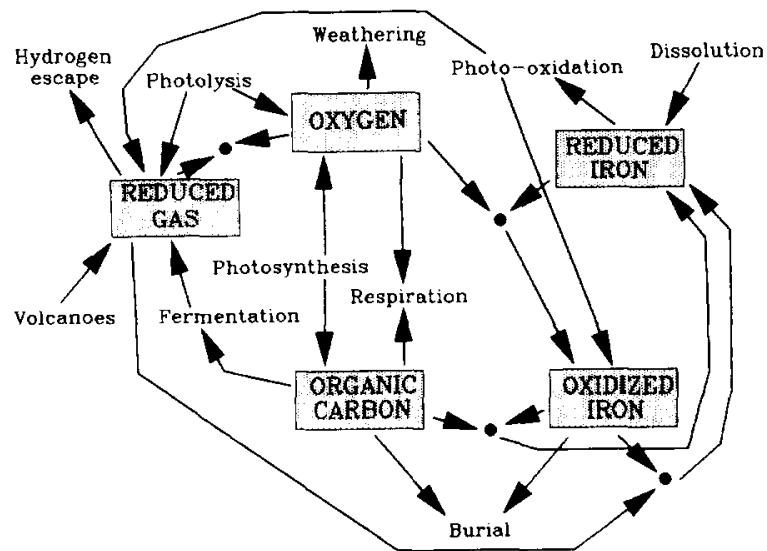

Fig. 8. Oxidation-reduction reactions in the simulated Archean biosphere.

methane on the other hand. Reduced dissolved iron is supplied to the deep ocean reservoir by sea floor hydrothermal interactions at a constant rate of $10^{13} \mathrm{~mole} / \mathrm{yr}$, somewhat higher than estimates of the combined iron and manganese flux at present (Edmond et al., $1979 a, b)$. This iron is removed from the ocean either by first order precipitation in silicate and carbonate minerals containing reduced iron or as oxidized iron. Oxidized iron is produced by reaction with dissolved oxygen in both the surface and deep ocean reservoirs at rates proportional to the products of the concentrations of dissolved oxygen and dissolved reduced iron. The oxidized iron is presumed to be in particulate form and to settle to the bottom of the ocean. Particulate oxidized iron is also produced by photostimulated oxidation in the shallow ocean at a rate proportional to the concentration of dissolved ferrous iron and inversely proportional to the concentration of dissolved reduced gases (Cairns-Smith, 1978; Braterman et al., 1983). The photostimulated oxidation of iron produces hydrogen as fast as it produces oxidized iron so the process is to some extent self-regulating (François, 1986). The hydrogen reacts with oxygen in the atmosphere and in both oceanic reservoirs. It also escapes to space. The reaction rates are first order in reactant concentrations and the escape rate is first order in hydrogen concentration (Hunten, 1973; Walker, 1977; Hunten et al., 1989). Escape to space of hydro- gen produced by photolysis of atmospheric water vapor is also included. It constitutes the only source of free oxygen before the origin of photosynthesis. There is a constant source of volcanic hydrogen with a flux of $2 \times 10^{11}$ mole $/ y r$ into the atmosphere. Reduced gases are generated by biological fermentation reactions at a rate proportional to the mass of reactive organic carbon. Reactive organic carbon is destroyed by diagenetic reactions with particulate iron as well as fermentation. The reaction restores dissolved carbon to the surface ocean reservoir and converts particulate iron back into dissolved reduced iron in the surface ocean reservoir. Particulate iron is consumed also in presumably abiological reactions with dissolved reduced gases (McKnight et al., 1988) and it undergoes incorporation into long-lived sedimentary rocks at a rate proportional to the mass of particulate iron.

The oxidation-reduction properties of the Archean world are dominated by the flux of reduced iron (and manganese) from the sea floor, which embraces any flux of dissolved oxygen into the sea floor. Release of dissolved ferrous iron by continental weathering is proportional to continental area and is initially negligibly small. Most of this mantle flux of iron is returned to the sea floor as iron silicate and carbonate minerals (Fig. 9). A small fraction is oxidized by the oxygen generated from photoly-

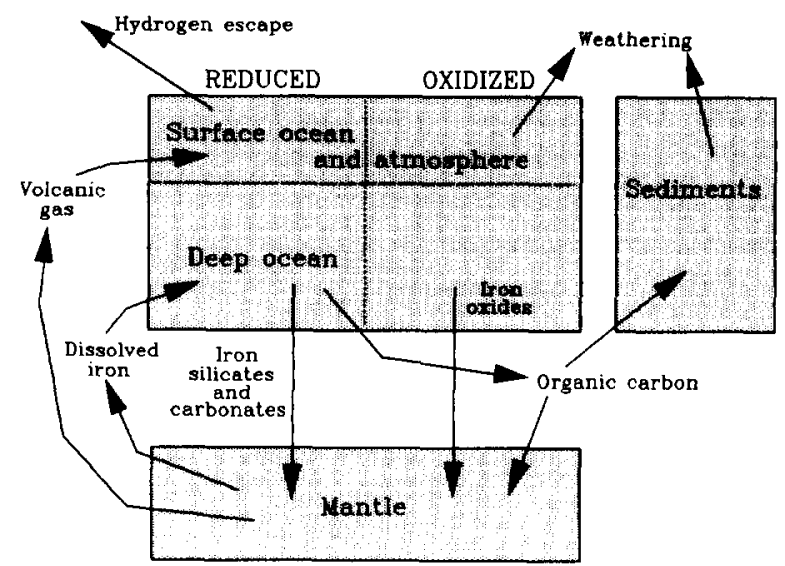

Fig. 9. The overall oxidation-reduction balance of the exogenic system depends on exchange with the mantle and the escape of hydrogen to space. 


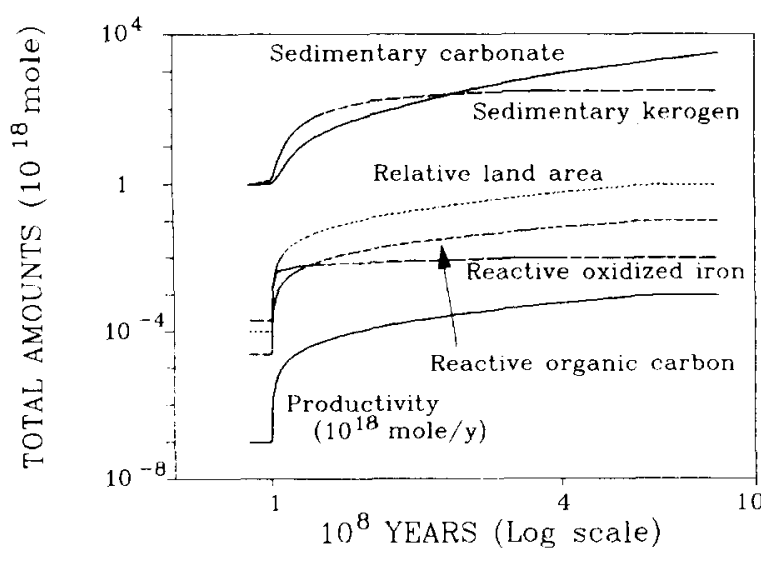

Fig. 10. Calculated response of the reservoirs of sedimentary carbonate, sedimentary kerogen, reactive oxidized iron, and reactive organic carbon to an assumed linear increase in land area and in biological productivity. Land area and productivity increase at a constant rate for 500 million years, beginning at 100 million years on this scale. The time scale is logarithmic.

sis of atmospheric water vapor or as a result of photostimulated oxidation in the surface layer of the ocean. This particulate iron carries oxygen out of the exogenic system back to the sea floor. The oxidation budget of the exogenic system balances the escape of hydrogen to space against this export of oxygen in the form of oxidized iron on the sea floor.

After the transition to the Proterozoic world, essentially all of the mantle flux of dissolved iron is promptly oxidized by dissolved oxygen and incorporated as oxidized iron into the sea floor. This much larger export of oxygen from the exogenic system must be balanced by a larger flux of hydrogen escaping to space because this system lacks plankton and the deep sea precipitation of organic carbon which might otherwise export reductant to the mantle to balance the export of oxygen. The accumulation of new sedimentary kerogen is balanced, after a short period of adjustment, by the oxidation of old sedimentary kerogen (Fig. 10). The Proterozoic world therefore exhibits higher atmospheric concentrations of reduced gases than the Archean world. These reduced gases are generated by fermentation of organic matter (Fig. 8), a source that increases markedly as productivity increases and the global store of reactive organic carbon in- creases (Fig. 10). The increased rate of production of reduced gases predominates over their increased rate of destruction in photochemical reactions with atmospheric oxidants. Fermentation and suboxic diagenetic reactions between oxidized iron and organic carbon must be included in the Archean simulation to recycle organic matter. In the Proterozoic world their recycling roles are minor compared with aerobic respiration.

\section{Results of the calculation}

The calculation is begun at an arbitrary time of $90 \times 10^{6} \mathrm{yr}$ and run for $10 \times 10^{6} \mathrm{yr}$ without change in parameters just to establish that a steady state Archean world has been created. Land area and productivity, which is proportional to land area, increase linearly by a factor of $10^{4}$ between $100 \times 10^{6} \mathrm{yr}$ and $600 \times 10^{6} \mathrm{yr}$ and remain constant thereafter. Figure 10 shows land area and productivity, the sedimentary reservoirs of kerogen and carbonate, and the shelf reservoir of reactive organic carbon. The reactive organic carbon reservoir increases more or less proportionally to productivity. The sedimentary kerogen reservoir comes to a steady state, a balance between oxidation of old kerogen and incorporation of new kerogen into the sedimentary reservoir. As already noted the reservoir of sedimentary carbonates continues to increase as a result of addition of mantle carbon to the exogenic system.

Figure 11 shows the transitions in the oxidation-reduction system. A logarithmic time scale is used to show the rapid initial response. Biologically produced oxygen overwhelms dissolved iron in the surface ocean very early in the course of the transition. Particulate iron (Fig. 10) rises to a nearly constant value as quickly as dissolved iron in the surface ocean reservoir falls. Very early in the transition there is a small maximum in the concentrations of dissolved reduced gases in both reservoirs caused by fermentation before oxygen concentrations build up enough to make respiration the major sink for reactive organic carbon. There follows a period of 200 million years or so during which produc- 
tivity increases steadily and the concentrations of reactive organic carbon and dissolved oxygen in both surface and deep reservoirs increase gradually. The concentration of dissolved reduced iron in the surface ocean reservoir also increases during this time as a result of the reaction between particulate oxidized iron and reactive organic carbon. During this time the deep sea remains anoxic, with a concentration of dissolved reduced iron well in excess of the concentration of dissolved oxygen. This condition reflects the sea floor hydrothermal source of reduced iron, which exceeds the rate of supply of dissolved oxygen by mixing downwards from the surface ocean. After about 300 million years, however, the surface oxygen source overwhelms the deep sea iron source and a rapid transition occurs; the deep sea becomes aerobic. This time corresponds loosely to the end of deposition of banded iron-formations, approximately $1.7 \times 10^{9}$ yr ago (Gole and Klein, 1981; Walker et al., 1983). Corresponding to the sudden increase in dissolved oxygen in the deep sea is a sudden decrease in dissolved reduced gases. The reduced gas concentration in surface ocean and atmosphere is increasing throughout this time period, as already noted, so that escape of hydrogen to space can carry away the reducing power added to the exogenic system by the flux of iron and reduced gas from the mantle.

At the beginning of the calculation the concentration of oxygen in surface ocean and atmo-

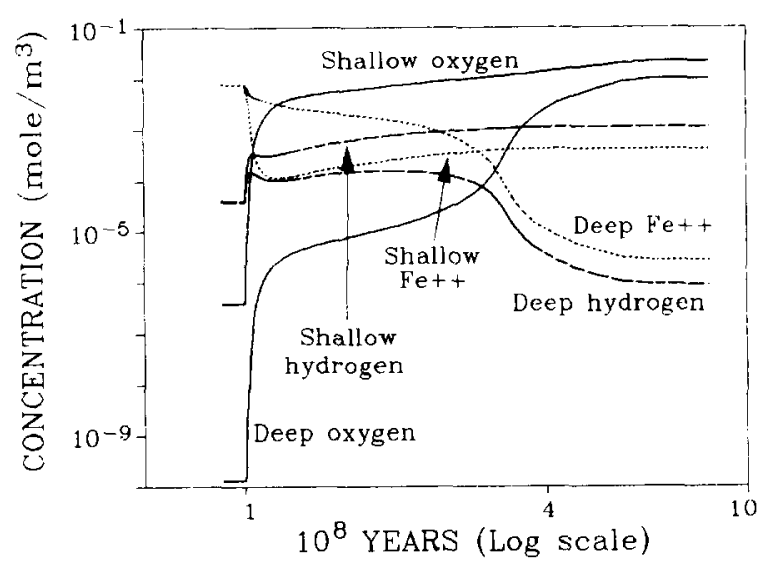

Fig. 11. Calculated response of oxygen, dissolved iron, and reduced gases in the shallow and deep ocean reservoirs.

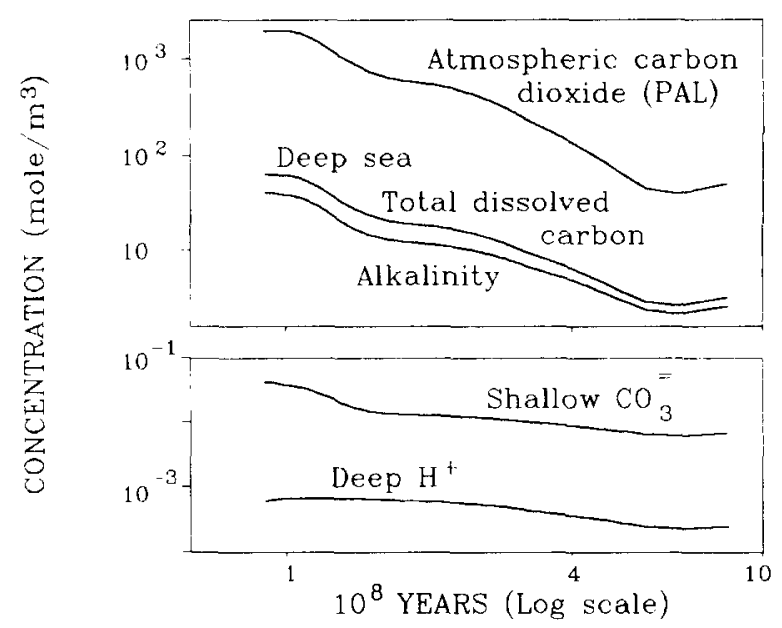

Fig. 12. Calculated response of atmospheric carbon dioxide (units relative to present level, PAL) and total dissolved carbon and alkalinity in the deep sea. Also shown is the carbonate concentration in shallow sea water, which is proportional to the saturation state with respect to calcium carbonate, and the hydrogen ion concentration in the deep sea.

sphere is less than the concentration of reduced gas. This is the anaerobic world in which life may have originated and undergone its early evolution. This is a world in which detrital uraninite would be preserved and redbeds would not form. It comes to an end very soon after productivity begins to increase, when the oxygen concentration rises above the reduced gas concentration. Very roughly, this time might correspond to the time, about $2.3 \times 10^{9} \mathrm{yr}$ ago, when redbeds first began to form (Walker et al., 1983). The value of the calculation is in its demonstration that these important transitions can be separated widely in time simply as a consequence of a gradual increase in biological productivity.

The response of the carbon system is shown in Fig. 12. The system has been tuned to yield a starting value of carbon dioxide partial pressure of a few thousand times the present level and an ending value of a hundred or so times the present level. This calculation establishes the possibility of such pressures but it does not establish their necessity or reality. Similarly, the calculation has been tuned to yield the more or less reasonable values of carbonate ion concentration 
in the surface ocean and hydrogen ion concentration in the deep ocean that are shown in Fig. 12. The value of the calculation lies in indicating what kinds of conditions must be satisfied to yield such large carbon dioxide pressures. Clearly a relatively acidic ocean is more or less unavoidable, even with alkalinity and total dissolved carbon concentrations very much larger than those of the present day. Moreover, to sustain such a large concentration of hydrogen ions there must be a very significant difference between total dissolved carbon concentration and alkalinity, a difference that is quite small in the present ocean. The carbon dioxide partial pressure in the Archean world is determined by the requirement that sea floor weathering consume carbon dioxide as fast as the mantle is releasing it. The weathering rate, in this simulation, depends on the hydrogen ion concentration and the total dissolved carbon concentration. The overall decrease in carbon dioxide during the course of the transition reflects the transfer of control to the continental weathering system. Continental weathering makes negligible contribution to the Archean simulation and sea floor weathering makes a negligible contribution to the Proterozoic simulation. Right near the end of the simulation (after $6 \times 10^{8} \mathrm{yr}$ in Fig. 12) we see carbon dioxide partial pressure and total dissolved carbon and alkalinity increasing again. This increase reflects the steadily growing reservoir of sedimentary carbonate rocks and the increased source of carbon dioxide provided by metamorphic decarbonation of these rocks. As already noted, the sedimentary carbonate reservoir is growing in this simulation as a result of the transfer of carbon out of the mantle.

The influence of the oxidation-reduction system on the carbon system appears as an initially rapid decrease in the parameters plotted in Fig. 12 in the first $50 \times 10^{6} \mathrm{yr}$ or so of the transition, which begins at a time of $100 \times 10^{6} \mathrm{yr}$. This drawdown of carbon in atmosphere and ocean is caused by the rapid growth of the sedimentary kerogen reservoir during this period of time. It is possible that Precambrian climate may have been affected by two separate episodes of carbon dioxide decline, one caused by the accumulation of sedimentary kerogen and the other caused by the growth of land area, the increase in terrestrial weathering, and the accumulation of the sedimentary carbonate reservoir.

\section{Discussion}

The value of the simulation presented here lies not so much in the numbers calculated for carbon dioxide and the other environmental parameters as the questions arising out of this computational exercise. If we are to understand the carbon cycle on an Archean Earth with little life or land area we need more knowledge about weathering reactions on the sea floor. The simulation confirms that carbon dioxide partial pressures large enough to solve the problem of the faint young sun can be achieved in a geochemical system that is at least plausible, but it shows once again that large carbon dioxide pressures imply large total dissolved carbon, alkalinity, and hydrogen ion concentrations in sea water. The implications of such large concentrations for the composition and mineralogy of sedimentary rocks need to be considered.

The simulation confirms what has been suspected for some time, that the growth of biological productivity could cause a marked decrease in atmospheric carbon dioxide and so also in global average temperature. This decrease might have played a role in the Huronian episode of wide-spread continental glaciation early in the Proterozoic. It would be worthwhile to extend the simulation to calculate the composition of carbon isotopes for comparison with observations of heavy carbon in this time period. The simulation also would benefit from incorporation of a sulfur cycle (Walker and Brimblecombe, 1985; Lowe and Byerly, 1986; Ohmoto and Felder, 1987, Kasting et al., 1989). A sulfur cycle could clearly influence the oxidation-reduction transition. It is not clear whether it would directly influence the carbon dioxide cycle and the climate.

While carbon dioxide still looks to me like the most important parameter in addition to reduced solar luminosity that would have affected 
the climates of the Precambrian Earth there are significant questions that should be susceptible to study with a global circulation model concerning the impact on the circulation of a shorter day and little or no land. Uncertainties concerning cloud cover continue to be a major source of concern, but it is not clear how to reduce them.

\section{Acknowledgement}

This research was supported in part by the National Aeronautics and Space Administration under grant NAGW-176. Theoretical research in paleoclimatology at the University of Michigan is carried out by a group that includes William Kuhn, Hal Marshall, Louis François, Greg Jenkins, and Eric Foote.

\section{Appendix 1 - The numerical simulation}

In this appendix I document the expressions used in the numerical simulation described above. I am presenting excerpts of the computer code, written in BASIC because I believe that such a method of presentation provides the most accurate record of the expressions that were actually used.

The dependent variables are:

\begin{tabular}{|c|c|c|}
\hline 1) & & $\begin{aligned}= & \text { oxygen diss } \\
& \text { ocean (mole }\end{aligned}$ \\
\hline 2) & $=\mathrm{c}$ & $\begin{aligned}= & \text { oxygen dissolved } \\
& \text { ean }\left(\mathrm{mole} / \mathrm{m}^{3}\right)\end{aligned}$ \\
\hline (3) & $=\mathrm{c}$ & $\begin{aligned}= & \text { global reservoir of reactive } \\
& \text { organic carbon }\left(10^{18} \text { moles }\right)\end{aligned}$ \\
\hline & $=$ pfe & $\begin{aligned}= & \text { reactive oxidized iron }\left(10^{18}\right. \\
& \text { moles })\end{aligned}$ \\
\hline & $=d$ & $\begin{aligned} &= \text { dis } \\
& \text { lor }\end{aligned}$ \\
\hline 6) & $=\mathrm{d}$ & $\begin{aligned} &= \text { dis } \\
& \text { oce }\end{aligned}$ \\
\hline 1 & $=d$ & $\begin{aligned}= & \mathrm{di} \\
& \mathrm{lo}\end{aligned}$ \\
\hline (8) & $=\mathrm{c}$ & ed gas in deep \\
\hline 20 & $=\mathrm{se}$ & $\begin{aligned}= & \text { glo } \\
& \operatorname{tar}\end{aligned}$ \\
\hline & & $\begin{aligned}= & \text { tot } \\
& \text { lov }\end{aligned}$ \\
\hline
\end{tabular}

$\mathrm{y}(11)=$ cdeep $=$ total dissolved carbon in deep ocean (mole $\left./ \mathrm{m}^{3}\right)$

$\mathrm{y}(12)=$ asurf $=$ alkalinity in shallow ocean $\left(\mathrm{mole} / \mathrm{m}^{3}\right)$

$y(13)=$ adeep $=$ alkalinity in deep ocean $\left(\mathrm{mole} / \mathrm{m}^{3}\right)$

$\mathrm{y}(14)=\mathrm{pco} 2=$ carbon dioxide partial pressure (PAL, relative to present level)

$\mathrm{y}(15)=$ sedcarb $=$ global reservoir of sedimentary carbonate $\left(10^{18}\right.$ moles)

The rates of change of these variables are given by the expressions for yp (i):

'Program ORIGN07.BAS. 24 July 1989

$$
\begin{aligned}
& \mathrm{yp}(1)=\operatorname{prod}-\mathrm{kfe} * \text { dfes } * \text { doxys } * \text { vols }- \\
& \text { wflux * (doxys - doxyd) + escbg } \\
& \mathrm{yp}(1)=(\mathrm{yp}(1)-\mathrm{koh} * \text { doxys } * \text { dh2s } * \text { vols }- \\
& \text { skox } * \text { doxys } * \text { sedker }) \\
& \mathrm{yp}(1)=(\mathrm{yp}(1)-\mathrm{koc} * \operatorname{corg} * \text { doxys }) /(\text { vols }+ \\
& \text { vola) } \\
& \mathrm{yp}(2)=\text { wflux } *(\text { doxys }- \text { doxyd }) \\
& \mathrm{yp}(2)=(\mathrm{yp}(2)-\mathrm{kfe} * \text { dfed } * \text { doxyd } * \text { vold }- \\
& \text { koh * doxyd * dh2d * vold)/vold } \\
& \mathrm{yp}(3)=\operatorname{prod}-\operatorname{koc} * \operatorname{corg} * \text { doxys }-\mathrm{kcpfe} * \\
& \text { pfe * corg } \\
& \mathrm{yp}(3)=\mathrm{yp}(3)-\operatorname{corg} / \text { btime }- \text { ferm * corg } \\
& \text { yp(4) }=\mathrm{kfe} * \text { dfed } * \text { doxyd } * \text { vold }+\mathrm{kfe} * \text { dfes } \\
& * \text { doxys * vols }+ \text { phox * dfes } \\
& \mathrm{yp}(4)=\mathrm{yp}(4)-\mathrm{kcpfe} * \text { pfe } * \text { corg }- \text { pfe } / \text { btime } \\
& -\mathrm{kfh} * \mathrm{pfe} * \mathrm{dh} 2 \mathrm{~d} \\
& \text { yp(5) }=(\text { wflux } *(\text { dfed }- \text { dfes })-\text { kfe } * \text { dfes * } \\
& \text { doxys * vols }- \text { phox * dfes) } \\
& \operatorname{yp}(5)=(\mathrm{yp}(5)+\mathrm{kcpfe} * \mathrm{pfe} * \text { corg }) / \text { vols } \\
& \text { yp }(6)=- \text { wflux } *(\text { dfed }-\mathrm{dfes})-\mathrm{kfe} * \mathrm{dfed} * \\
& \text { doxyd * vold } \\
& \operatorname{yp}(6)=(\operatorname{yp}(6)-\text { dfed } * \text { vold } / \text { precip }+ \text { feflux }+ \\
& \text { kfh * pfe * dh2d)/vold } \\
& \text { yp }(7)=\text { phox } * \text { dfes }- \text { wflux } *(\text { dh2s }-\mathrm{dh} 2 d)+ \\
& \text { volch - esc * dh } 2 \mathrm{~s} * \text { volah } \\
& \mathrm{yp}(7)=(\mathrm{yp}(7)+\text { ferm } * \text { corg }- \text { koh } * \text { doxys * } \\
& \text { dh2s * vols }) /(\text { vols }+ \text { volah }) \\
& y p(8)=\text { wflux } *(\text { dh2s }- \text { dh2d })-\text { koh } * \text { doxyd } \\
& \text { * dh2d * vold } \\
& y p(8)=(y p(8)-k f h * p f e * d h 2 d) / \text { vold } \\
& \text { yp(9) }=\text { cfrac * corg/btime }- \text { skox * doxys * } \\
& \text { sedker }- \text { volcz } * \text { sedker }
\end{aligned}
$$




$$
\begin{aligned}
& \text { yp }(10)=(\text { cdeep }- \text { csurf }) * \text { wflux }+ \text { carbw }- \text { prod } \\
& *(1+\text { corat })+\text { skox } * \text { doxys } * \text { sedker } \\
& \mathrm{yp}(10)=\mathrm{yp}(10)+\mathrm{koc} * \operatorname{corg} * \text { doxys }+\mathrm{kcpfe} * \\
& \text { pfe } * \text { corg }+ \text { ferm * corg } \\
& \mathrm{yp}(10)=(\mathrm{yp}(10)+(\mathrm{pco} 2-\mathrm{pco} 2 \mathrm{~s}) / \text { distime * } \\
& \text { matmco2)/vols } \\
& \operatorname{yp}(11)=((\text { csurf }- \text { cdeep }) * \text { wflux }+ \text { morc }- \text { sfw * } \\
& \text { cdeep)/vold } \\
& \text { yp }(12)=(-(\text { asurf }- \text { adeep }) \quad * \quad \text { wflux }+2 \quad * \\
& (\text { carbw }+ \text { silw })-\operatorname{prod} * 2 * \text { corat }) / \text { vols } \\
& y p(13)=((\text { asurf }- \text { adeep }) * \text { wflux }+ \text { sfw }- \text { hydro } \\
& \text { * adeep)/vold } \\
& \operatorname{yp}(14)=(p \operatorname{po} 2 \mathrm{~s}-\mathrm{pco} 2) / \text { distime }+ \text { volcz * } \\
& \text { (sedcarb + sedker)/matmco2 } \\
& \text { yp }(15)=\text { cfrac } * \text { prod } * \text { corat }- \text { carbw }- \text { volcz } *
\end{aligned}
$$

Where the parameters have the values listed here:

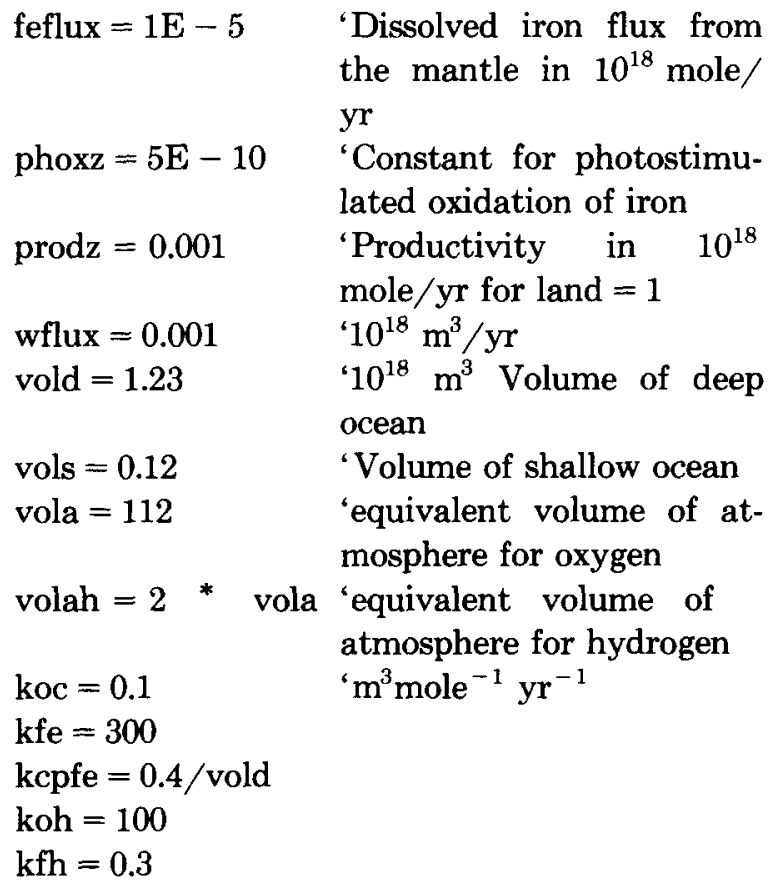

skox $=0.000015$

btime $=1000$

cfrac $=1$

ferm $=3 /$ btime

precip $=1000$

volch $=0.0000002$

$\mathrm{escbg}=1 \mathrm{E}-08$ esc $=0.000039$

'The carbon system coratz $=1$

Biological ratio of carbonate to organic carbon

matmco2 $=0.0495$ ' $10^{18}$ mole. $280 \mathrm{ppm}=1$ PAL

distime $=8.64 \quad$ 'years

sfwcon $=0.1$

'Sea floor weathering

tbart $=288$

'Shallow water temperature

$\mathrm{tdw}=275 \quad$ 'Deep water temperature

'Constants related to the rock cycle

volcz $=5 \mathrm{E}-10 \quad$ 'Fluxes in $10^{18} \mathrm{~mole} / \mathrm{yr}$

morc $=0.000005 \quad$ 'MOR carbon flux

carbwz $=0.0000003$

silwz $=0.000002$

hydro $=1 \mathrm{E}-8$

'High temperature sink for alkalinity, eq/yr

The derived quantities are given by the following expressions:

phox $=$ phoxz $/$ dh $2 \mathrm{~s}$

$\operatorname{pco} 2 \mathrm{~s}=\mathrm{kco} 2 *$ hco3s $2 / \operatorname{co} 3 \mathrm{~s}$

$\operatorname{prod}=\operatorname{prodz} *$ land $* \operatorname{pco} 2 \mathrm{~s} /(1+\operatorname{pco} 2 \mathrm{~s})$

corat $=$ coratz $*$ co3s

hplusd $=$ hco3d $/ \operatorname{co} 3 \mathrm{~d} * 7.94 \mathrm{E}-10$

sfw $=$ sfwcon $*$ hplusd

silw $=$ silwz $* \operatorname{pco} 2 \hat{.} 3 *$ land

carbw $=$ carbwz $*$ pco $2 \wedge .3 *$ sedcarb $/ 5000$

The following subroutine calculates equilibrium concentrations of dissolved carbon species in terms of alkalinity (alk), total dissolved carbon (sigc), and water temperature (watemp):

CARBONATE:

'Subroutine solves

the carbonate equilibria

$\mathrm{kcarb}=.000575+.000006 *($ watemp -278$)$

$\mathrm{kco} 2=.035+.0019 *($ watemp -278$)$

hco3 = sigc - SQR(sigc $2-$ alk * (2* sigc alk) * $(1-4 *$ kcarb $))$

hco3 $=$ hco3 $/(1-4 *$ kcarb $)$

'continuation

$\operatorname{co} 3=($ alk $-\mathrm{hco} 3) / 2$

RETURN

The calculation steps forward in time from prescribed initial conditions using the completely implicit reverse Euler method of solution. 


\section{References}

Aharon, P., Schidlowski, M. and Singh, I.B., 1987. Chronostratigraphic markers in the end-Precambrian carbon isotope record of the Lesser Himalaya, Nature, 327: 699 702.

Algeo, T.J. and Wilkinson, B.H., 1988. Periodicity of mesoscale Phanerozoic sedimentary cycles and the role of Milankovitch orbital modulation. J. Geol, 96: 313-322.

Allegre, C.J., Staudacher, T. and Sarda, P., 1987. Rare gas systematics: formation of the atmosphere, evolution and structure of the Earth's mantle. Earth Planet. Sci. Lett. 81: $127-150$.

Arthur, M.A., Dean, W.E. and Pratt, L.M., 1988. Geochemical and climatic effects of increased marine organic carbon burial at the Cenomanian/Turonian boundary. Nature 335: 714-717.

Awramik, S.M., 1986. New fossil finds in old rocks. Nature, 319: $446-447$.

Baker, A.J. and Fallick, A.E., 1989a. Evidence from Lewisian limestones for isotopically heavy carbon in two-thousand-million-year-old sea water. Nature, 337: 352-354.

Baker, A.J. and Fallick, A.E., 1989b. Heavy carbon in twobillon-year-old marbles from Lofoten-Vesteralen, Norway: Implications for the Precambrian carbon cycle. $\mathrm{Ge}$ ochim. Cosmochim. Acta, 53: 1111-1115.

Berg, G.W., 1986. Evidence for carbonate in the mantle. Nature, 324: 50-51.

Berger, A., Loutre, M.F. and Dehant, V. 1989. Influence of the changing lunar orbit on the astronomical frequencies of pre-Quaternary insolation patterns. Paleoceanography, 4: 555-564.

Berner, R.A., 1982. Burial of organic carbon and pyrite in the modern ocean: Its geochemical and environmental significance. Am. J. Sci., 282: 451-473.

Berner, R.A., Lasaga, A.C. and Garrels, R.M., 1983. The carbonate-silicate geochemical cycle and its effect on atmospheric carbon dioxide over the past 100 million years. Am. J. Sci., 283: 641-683.

Berner, R.A. and Canfield, D.E., 1989. A new model for atmospheric oxygen over Phanerozoic time. Am. J. Sci., 289: $333-361$.

Bickford, M.E., 1988. The formation of continental crust: Part 1. A review of some principles; Part 2. An application to the Proterozoic evolution of southern North America. Geol. Soc. Am. Bull., 100: 1375-1391.

Bowring, S.A., King, J.E., Housh, T.B., Isachsen, C.E. and Podosek, F.A., 1989. Neodymium and lead isotope evidence for enriched early Archaean crust in north America. Nature, 340: 222-225.

Braterman, P.S., Cairns-Smith, A.G. and Sloper, R.W., 1983. Photo-oxidation of hydrated $\mathrm{Fe} 2+$ : significance for banded iron formations. Nature, 303: 163-164.

Brock, T.D., 1978. Thermophilic Microorganisms and Life at High Temperatures, Springer, New York, N.Y. 465 pp.

Brock, T.D., 1985. Life at high temperatures. Science, 230: $132-138$.

Broecker, W.S., 1971. A kinetic model for the chemical composition of sea water. Quat. Res., 1: 188-207.
Broecker, W.S. and Peng, T.-H., 1982. Tracers in the Sea. Lamont-Doherty Geol. Observatory, Palisades, New York, $690 \mathrm{pp}$.

Budyko, M.I., 1969. The effect of solar radiation variations on the climate of the Earth. Tellus, 21: 611-619.

Byerly, G.R., Lowe, D.R. and Walsh, M.M., 1986. Stromatolites from the 3,300-3,500-Myr Swaziland Supergroup, Barberton Mountain Land, South Africa. Nature, 319: 489-491.

Cairns-Smith, A.G., 1978. Precambrian solution photochemistry, inverse segregation and banded iron formations. Nature, 276: 807-808.

Canuto, V.M., Levine, J.S., Augustsson, T.R. and Imhoff, C.L., 1982. UV radiation from the young sun and oxygen and ozone levels in the prebiological palaeoatmosphere. Nature, 296: 816-820.

Cloud, P.E., 1968. Atmospheric and hydrospheric evolution on the primitive Earth. Science, 160: 729-736.

Cloud, P.E., 1973. Paleoecological significance of the banded iron-formation. Econ. Geol., 68: 1135-1143.

Cogley, J.G. and Henderson-Sellers, A., 1984. The origin and earliest state of the Earth's hydrosphere. Rev. Geophys. 22: $131-175$.

Condie, K.C., 1986. Origin and early growth rate of continents. Precambrian Res., 32: 261-278.

Condie, K.C., 1989. Origin of the Earth's crust. Global Planet Change, 1: 57-81.

Crowley, T.J., 1983. The geologic record of climatic change. Rev. Geophys. Space Phys., 21: 828-877.

Daniels, L., Belay, N., Rajagopal, B.S. and Weimer, P.J., 1987. Bacterial methanogenesis and growth from $\mathrm{CO}_{2}$ with elemental iron as the sole source of electrons. Science, 237: 509-511.

Dean, W.E., Arthur, M.A. and Claypool, G.E., 1986. Depletion of ${ }^{13} \mathrm{C}$ in Cretaceous marine organic matter: source, diagenetic, or environmental signal? Mar. Geol., 70: 119157.

Des Marais, D.J., 1985. Carbon exchange between the mantle and the crust and its effect upon the atmosphere: Today compared to Archean time. In: E.T. Sundquist and W.S. Broecker (Editors), Natural Variations in Carbon Dioxide and the Carbon Cycle. Am. Geophys. Union, Washington, D.C., pp. 602-611.

Dimroth, E. and Kimberley, M.M., 1976. Precambrian atmospheric oxygen: evidence in the sedimentary distributions of carbon, sulfur, uranium and iron. Can. J. Earth Sci., 13: $1161-1185$.

Dimroth, E. and Lichtblau, A.P., 1978. Oxygen in the Archean ocean: Comparison of ferric oxide crusts on Archean and Cainozoic pillow basalts. Neues Jahrb. Mineral. Abh., 133: 1-22.

Edmond, J.M., Measures, C., Mangum, B., Grant, B., Sclater, F.R., Collier, R., Hudson, A. and Gordon, L.I., 1979. On the formation of metal-rich deposits at ridge crests. Earth Planet. Sci. Lett., 46: 19-30.

Edmond, J.M., Measures, C., McDuff, R.E., Chan, L.H., Collier, R., Grant, B., Gordon, L.I. and Corliss, J.B., 1979. Ridge crest hydrothermal activity and the balances of the major and minor elements in the ocean: The Galapagos data. Earth Planet. Sci. Lett., 46: 1-18. 
Embleton, B.J.J. and Williams, G.E., 1986. Low paleolatitude of deposition for late Precambrian periglacial varvites in South Australia: implications for palaeoclimatology. Earth Planet. Sci. Lett., 79: 419-430.

Eriksson, K.A. and Donaldson, J.A., 1986. Basinal and shelf sedimentation in relation to the Archaean-Proterozoic boundary. Precambrian Res., 33: 103-121.

Frakes, L.A., 1979. Climates Throughout Geologic Time. Elsevier, Amsterdam, 310 pp.

Frakes, L.A. and Francis, J.E., 1988. A guide to Phanerozoic cold polar climates from high-latitude ice-rafting in the Cretaceous. Nature, 333: 547-549.

François, L.M., 1986. Extensive deposition of banded iron formations was possible without photosynthesis. Nature, 320: $352-354$.

François, L.M. and Gérard, J.-C., 1988. Ozone, climate and biospheric environment in the ancient oxygen-poor atmosphere. Planet. Space Sci., 36: 1391-1414.

Frankel, R.B., 1987. Anaerobes pumping iron. Nature, 330: 208.

Froelich, P.N., Klinkhammer, G.P., Bender, M.L., Luedtke, N.A., Heath, G.R., Cullen, D., Dauphin, P., Hammond, D. and Maynard, V., 1979. Early oxidation of organic matter in pelagic sediments of the eastern equatorial Atlantic: suboxic diagenesis. Geochim. Cosmochim. Acta, 43: $1075-1090$.

Goldstein, S.L., 1988. Decoupled evolution of $\mathrm{Nd}$ and $\mathrm{Sr}$ isotopes in the continental crust and the mantle. Nature, 336: 733-738.

Gole, M.J. and Klein, C., 1981. Banded iron-formations through much of Precambrian time. J. Geol., 89: 169-183.

Goodfellow, W.D., 1986. Anoxic oceans and short-term carbon isotope trends. Nature, 322: 116-117.

Gough, D.O., 1977. Theoretical predictions of variations of the solar output. In: O.R. White (Editor), The Solar Output and its Variations. Univ. Colorado Press, Boulder, Color., pp. 451-473.

Gough, D.O. and Weiss, N.O., 1976. The calibration of stellar convection theories. Mon. Not. R. Astron. Soc., 176: 589-607.

Grandstaff, D.E., Edelman, M.J., Foster, R.W., Zbinden, E. and Kimberley, M.M., 1986. Chemistry and mineralogy of Precambrian paleosols at the base of the Dominion and Pongola Groups (Transvaal, South Africa). Precambrian Res., 32: 97-101.

Gregory, R.T. and Taylor, H.P., 1981. An oxygen isotope profile in a section of Cretaceous oceanic crust, Samail ophiolite, Oman: Evidence for delta ${ }^{18} \mathrm{O}$ buffering of the oceans by deep ( $>5 \mathrm{~km}$ ) seawater hydrothermal circulation at midocean ridges. J. Geophys. Res., 86: 2737-2755.

Grotzinger, J.P., 1986. Cyclicity and paleoenvironmental dynamics, Rocknest platform, northwest Canada. Geol. Soc. Am. Bull., 97: 1208-1231.

Gurnis, M. and Davies, G.F., 1986. Apparent episodic crustal growth arising from a smoothly evolving mantle. Geology, 14: 396-399.

Hallam, A., 1986. Origin of minor limestone-shale cycles: Climatically induced or diagenetic? Geology, 14: 609-612.

Hambrey, M. and Harland, W.B., 1981. Earth's Pre-Pleistocene Glacial Record, Cambridge Univ. Press, Cambridge.
Hargraves, R.B., 1986. Faster spreading or greater ridge length in the Archean? Geology, 14: 750-752.

Harker, R.I. and Giegengack, R., 1989. Brecciation of clasts in diamictites of the Gowganda Formation, Ontario, Canada. Geology, 17: 123-126.

Harley, S.L., 1987. Origin and growth of continents. Nature, 329: 108-109.

Henderson-Sellers, A., 1978. The Earth's evolution and paleoclimatology - A computational model. Comput. GeoSci., 4: 319-331.

Henderson-Sellers, A., 1978. Surface type and its effect upon could cover: A climatological investigation. J. Geophys. Res., 83: 5057-5062.

Henderson-Sellers, A., 1979. Clouds and the long-term stability of the Earth's atmosphere and climate. Nature, 279: $786-788$.

Henderson-Sellers, A. and Cogley, J.G., 1982. The Earth's early hydrosphere. Nature, 298: 832-835.

Henderson-Sellers, A. and Henderson-Sellers, B., 1988. Equable climate in the early Archaean. Nature, 336: $117-118$.

Henderson-Sellers, A. and Meadows, A.J., 1979. The zonal and global albedoes of the earth. Tellus, 31: 170-173.

Hoffman, P.F., 1989. Speculations on Laurentia's first gigayear (2.0 to $1.0 \mathrm{Ga})$. Geology, 17: 135-138.

Holland, H.D., 1973. Ocean water, nutrients and atmospheric oxygen. Proceedings of Symposium on Hydrogeochemistry and Biogeochemistry. Clarke, Washington, D.C., 1 , pp. $68-81$.

Holland, H.D., 1978. The Chemistry of the Atmosphere and Oceans. Wiley, New York, N.Y., 351 pp.

Holland, H.D., 1984. The Chemical Evolution of the Atmosphere and Oceans. Princeton Univ. Press, Princeton, N.J., 582 pp.

Hunt, B.G., 1979a. The effects of past variations of the Earth's rotation rate on climate. Nature, 281: 188-191.

Hunt, B.G., 1979b. The influence of the Earth's rotation rate on the general circulation of the atmosphere. J. Atmos. Sci., 36: 1392-1408.

Hunt, B.G., 1980. Reply to G.E. Williams. Nature, 286: 310.

Hunt, B.G., 1984. Polar glaciation and the genesis of ice ages. Nature, 308: 48-51.

Hunten, D.M., 1973. The escape of light gases from planetary atmospheres. J. Atmos. Sci., 30: 1481-1494.

Hunten, D.M., Donahue, T.M., Kasting, J.F. and Walker, J.C.G., 1989. Escape of atmospheres and loss of water. In: S.K. Atreya, J.B. Pollack and M.S. Matthes, (Editors), Origin and Evolution of Planetary and Satellite Atmospheres. Univ. Arizona Press, Tucson, Ariz., pp. 386-422.

Jacobsen, S.B., 1988. Isotopic and chemical constraints on mantle-crust evolution. Geochim. Cosmochim. Acta, 52: 1341-1350.

Javoy, M., Pineau, F. and Allegre, C.J., 1982. Carbon geodynamic cycle. Nature, 300: 171-173.

Karhu, J. and Epstein, S., 1986. The implication of the oxygen isotope records in coexisting cherts and phosphates. Geochim. Cosmochim. Acta, 50: 1745-1756.

Kasting, J.F., 1982. Stability of ammonia in the primitive terrestrial atmosphere. J. Geophys. Res., 87: 3091-3098.

Kasting, J.F., 1987. Theoretical constraints on oxygen and 
carbon dioxide concentrations in the Precambrian atmosphere. Precambrian Res., 34: 205-229.

Kasting, J.F., 1988. Runaway and moist greenhouse atmospheres and the evolution of Earth and Venus. Icarus, 4: 472-494.

Kasting, J.F. and Ackerman, T.P., 1986. Climatic consequences of very high carbon dioxide levels in the Earth's early atmosphere. Science, 234: 1383-1385.

Kasting, J.F. and Donahue, T.M., 1980. The evolution of atmospheric ozone. J. Geophys. Res., 85: 3255-3263.

Kasting, J.F. and Pollack, J.B., 1984. Effects of high $\mathrm{CO}_{2}$ levels on surface temperature and atmospheric oxidation state of the early Earth. J. Atmos. Chem., 1: 403-428.

Kasting, J.F., Zahnle, K.J., Pinto, J.P. and Young, A.T. 1989. Sulfur, ultraviolet radiation, and the early evolution of life. Origins of Life, 19: 95-108.

Kasting, J.F. and Walker, J.C.G., 1990. Long term effects of fossil fuel burning. Global Planet. Change, in prep.

Kasting, J.F., Zahnle, K.J. and Walker, J.C.G., 1983. Photochemistry of methane in the Earth's early atmosphere. Precambrian Res., 20: 121-148.

Knauth, L.P. and Epstein, S., 1976. Hydrogen and oxygen isotope ratios in nodular and bedded cherts. Geochim., Cosmochim. Acta, 40: 1095-1108.

Knauth, L.P. and Lowe, D.R., 1978. Oxygen isotope geochemistry of cherts from the Onverwacht Group (3.4 billion years), Transvaal, South Africa, with implications for secular variations in the isotopic composition of cherts, Earth Planet. Sci. Lett., 41: 209-222.

Knoll, A.H., 1979. Archean photoautotrophy: Some alternatives and limits. Origins of Life, 9: 313-327.

Knoll, A.H., Hayes, J.M., Kaufman, A.J., Swett, K. and Lambert, I.B., 1986. Secular variation in carbon isotope ratios from Upper Proterozoic successions of Svalbard and East Greenland. Nature, 321: 832-838.

Knoll, M.A. and James, W.C., 1987. Effect of the advent and diversification of vascular land plants on mineral weathering through geologic time. Geology, 15: 1099 1102.

Kolodny, Y. and Epstein, S., 1976. Stable isotope geochemistry of deep-sea cherts. Geochim. Cosmochim. Acta, 40: 1195-1209.

Kuhn, W.R. and Atreya, S.K., 1979. Ammonia photolysis and the greenhouse effect in the primordial atmosphere of the Earth. Icarus, 37: 207-213.

Kuhn, W.R. and Kasting, J.F., 1983. Effects of increased $\mathrm{CO}_{2}$ concentrations on surface temperatures of the early Earth. Nature, 301: 53-55.

Kuhn, W.R., Walker, J.C.G. and Marshall, H.G., 1989. The effect on Earth's surface temperature from variations in rotation rate, continent formation, solar luminosity and carbon dioxide. J. Geophys. Res., 94: 11129-11136.

Lambert, I.B., Walter, M.R., Wenlong, Z., Songnian, L. and Guogan, M., 1987. Palaeoenvironment and carbon isotope stratigraphy of Upper Proterozoic carbonates of the Yangtze Platform. Nature, 325: 140-142.

Lasaga, A.C., Berner, R.A. and Garrels, R.M., 1985. An improved model of atmospheric $\mathrm{CO}_{2}$ fluctuations over the past 100 million years. In: The Carbon Cycle and Atmospheric $\mathrm{CO}_{2}$ : Natural Variations Archean to Pre- sent. Am. Geophys. Union, Washington, D.C., pp. $397-$ 411.

Levine, J.S., 1985. The photochemistry of the early atmosphere. In: J.S. Levine (Editor), The Photochemistry of Atmospheres. Academic Press, Orlando, Fda., pp. 3-38.

Levine, J.S., Hays, P.B. and Walker, J.C.G., 1979. The evolution and variability of atmospheric ozone over geological time. Icarus, 39: 295-309.

Lovelock, J.E. and Whitfield, M., 1982. Life span of the biosphere. Nature, 296: 561-563.

Lovley, D.R., Stolz, J.F., Nord, G.L. and Phillips, E.J.P., 1987. Anaerobic production of magnetite by a dissimilatory iron-reducing microorganism. Nature, 330: 252-254.

Lowe, D.R. and Byerly, G.R., 1986. Archaean flow-top alteration zones formed initially in a low-temperature sulphate-rich environment. Nature, 324: 245-248.

Magaritz, M., Holser, W.T. and Kirschvink, J.L., 1986. Carbon-isotope events across the Precambrian/Cambrian boundary on the Siberian Platform. Nature, 320: 258-259.

Marshall, H.G., Walker, J.C.G. and Kuhn, W.R., 1988. Long-term climate change and the geochemical cycle of carbon. J. Geophys. Res., 93: 791-801.

Marty, B. and Jambon, A., 1987. C/ $/{ }^{3} \mathrm{He}$ in volatile fluxes from the solid Earth: implications for carbon geodynamics. Earth Planet. Sci. Lett., 83: 16-26.

McKnight, D.M., Kimball, B.A. and Bencala, K.E., 1988. Iron photoreduction and oxidation in an acidic mountain stream. Science, 240: 637-640.

Meybeck, M., 1979. Concentration des eaux fluviales en éléments majeurs et apports en solution aux océans. Rev. Géol. Dyn. Géogr. Phys., 21: 215-246.

Meybeck, M., 1987. Global chemical weathering of surficial rocks estimated from river dissolved loads. Am. J. Sci., 287: 401-428.

Mix, A.C., 1987. Hundred-kiloyear cycle queried. Nature, 327: 370 .

Muehlenbachs, K. and Clayton, R.N., 1976. Oxygen isotope composition of the oceanic crust and its bearing on seawater. J. Geophys. Res., 81: 4365-4369.

Mustard, P.S. and Donaldson, J.A., 1987. Early Proterozoic ice-proximal glaciomarine deposition: The lower Gowganda Formation at Cobalt, Ontario, Canada. Geol. Soc. Am. Bull., 98: 373-387.

Newman, M.J. and Rood, R.T., 1977. Implications of solar evolution for the Earth's early atmosphere. Science, 198: $1035-1037$.

Nisbet, E.G., 1987. The Young Earth. An Introduction to Archaean Geology. Allen and Unwin, London, 402 pp.

North, G.R., 1975. Theory of energy-balance climate models. J. Atmos. Sci., 32: 2033-2043.

North, G.R., Cahalan, R.F. and Coakley, J.A., 1981. Energy balance climate models. Rev. Geophys. Space Phys., 19: 91-121.

Ohmoto, H. and Felder, R.P., 1987. Bacterial activity in the warmer, sulphate-bearing, Archaean oceans. Nature, 328: 244-246.

Owen, T., Cess, R.D. and Ramanathan, V., 1979. Enhanced $\mathrm{CO}_{2}$ greenhouse to compensate for reduced solar luminosity on early Earth. Nature, 277: 640-642.

Perry, E.C. and Ahmad, S.N., 1983. Oxygen isotope geo- 
chemistry of Proterozoic chemical sediments. Geol. Soc. Am. Mem., 161: 253-263.

Perry, E.C. and Tan, F.C., 1972. Significance of oxygen and carbon isotope variations in early Precambrian cherts and carbonate rocks of southern Africa. Geol. Soc. Am. Bull., 83: 647-664.

Pinet, P. and Souriau, M., 1988. Continental erosion and large-scale relief. Tectonics, 7: 563-582.

Pollack, H.N., 1980. The heat flow from the Earth: A review. In: P.A. Davies and S.K. Runcorn (Editors), Mechanisms of Continental Drift and Plate Tectonics. Academic Press, New York, N.Y., pp. 183-192.

Pollack, H.N., 1986. Cratonization and thermal evolution of the mantle. Earth Planet. Sci. Lett., 80: 175-182.

Popp, B.N., Anderson, T.F. and Sandberg, P.A., 1986. Brachiopods as indicators of original isotopic compositions in some Paleozoic limestones. Geol. Soc. Am. Bull., 97: 1262-1269.

Popp, B.N., Takigiku, R., Hayes, J.M., Louda, J.W. and Baker, E.W., 1989. The post-Paleozoic chronology and mechanism of ${ }^{13} \mathrm{C}$ depletion in primary marine organic matter. Am. J. Sci., 289: 436-454.

Ramanathan, V., Cess, R.D., Harrison, E.F., Minnis, P., Barkstrom, B.R., Ahmad, E. and Hartmann, D., 1989. Cloud-radiative forcing and climate: Results from the Earth Radiation Budget Experiment. Science, 243: 57-63.

Ratner, M.I. and Walker, J.C.G., 1972. Atmospheric ozone and the history of life. J. Atmos. Sci., 29: $803 \neq 808$.

Rau, G.H., Takahashi, T. and Des Marais, D.J., 1989. Latitudinal variations in plankton delta ${ }^{13} \mathrm{C}$ : implications for $\mathrm{CO}_{2}$ and productivity in past oceans. Nature, 341: 516518 .

Retallack, G., 1986. Reappraisal of a 2200 Ma-old paleosol near Waterval Onder, South Africa. Precambrian Res., 32: 195-232.

Ringwood, A.E., 1961. Changes in solar luminosity and some possible terrestrial consequences. Geochim. Cosmochim. Acta, 21: 295-296.

Roberts, R.G., 1987. Ore deposit models No. 11. Archean lode gold deposits. Geosci. Can., 14: 37-52.

Rossow, W.B., Henderson-Sellers, A. and Weinreich, S.K., 1982. Cloud feedback: A stabilizing effect for the early earth? Science, 217: 1245-1247.

Sagan, C. and Mullen, G., 1972. Earth and Mars: Evolution of atmospheres and surface temperatures. Science, 177: $52-56$.

Schidlowski, M., 1988. A 3,800-million-year isotopic record of life from carbon in sedimentary rocks. Nature, 333: 313 318.

Schidlowski, M., Hayes, J.M. and Kaplan, I.R., 1983. Isotopic inferences of ancient biochemistries: carbon, sulfur, hydrogen and nitrogen. In: J.W. Schopf (Editor), Earth's Earliest Biosphere: Its Origin and Evolution. Princeton Univ. Press, Princeton, N.J., pp. 149-186.

Schopf, J.W. and Packer, B.M., 1987. Early Archean (3.3-billion to 3.5-billion-year-old) microfossils from Warrawoona Group, Australia. Science, 237: 70-73.

Schopf, J.W. and Walter, M.R., 1983. Archean microfossils: New evidence of ancient microbes. In: J.W. Schopf (Edi- tor), Earth's Earliest Biosphere: Its Origin and Evolution. Princeton Univ. Press, Princeton, N.J., pp. 214-239.

Sellers, W.D., 1969. A climate model based on energy balance of the Earth-atmosphere system. J. Appl. Meteorol., 8: $392-400$.

Sibley, D.F. and Vogel, T.A., 1976. Chemical mass balance of the Earth's crust: The calcium dilemma (?) and the role of pelagic sediments. Science, 192: 551-553.

Staudigel, H. and Hart, S.R., 1983. Alteration of basaltic glass: Mechanism and significance for the oceanic crustseawater budget. Geochim. Cosmochim. Acta, 47: 337 350.

Stone, P.H., 1972. A simplified radiative-dynamical model for the static stability of rotating atmospheres. J. Atmos. Sci., 29: 405-418.

Stump, E., Miller, J.M.G., Korsch, R.J. and Edgerton, D.G., 1988. Diamictite from Nimrod Glacier area, Antarctica: Possible Proterozoic glaciation on the seventh continent. Geology, 16: 225-228.

Taylor, S.R. and McLennan, S.M., 1985. The Continental Crust: Its Composition and Evolution. Blackwell, Oxford, $312 \mathrm{pp}$.

Thompson, S.L. and Barron, E.J., 1981. Comparison of Cretaceous and present Earth albedos: Implications for the causes of paleoclimates. J. Geol., 89: 143-167.

Tingle, T.N. and Green, H.W., 1987. Carbon solubility in olivine: Implications for upper mantle evolution. Geology, 15: 324-326.

Towe, K.M., 1978. Early Precambrian oxygen: a case against photosynthesis. Nature, 274: 657-661.

Towe, K.M., 1981. Environmental conditions surrounding the origin and early Archean evolution of life: A hypothesis. Precambrian Res., 16: 1-10.

Towe, K.M., 1983. Precambrian atmospheric oxygen and banded iron formations: A delayed ocean model. Precambrian Res., 20: 161-170.

Trendall, A.F., 1983. In: A.F. Trendall and R.C. Morris (Editors), The Hamersley Basin Iron Formation: Facts and Problems. Elsevier, Amsterdam, pp. 69-130.

Twist, D. and Cheney, E.S., 1986. Evidence for the transition to an oxygen-rich atmosphere in the Rooiberg Group, South Africa-a note. Precambrian Res., 33: 255-264.

Veevers, J.J. and Powell, C. McA., 1987. Late Paleozoic glacial episodes in Gondwanaland reflected in transgressive-regressive depositional sequences in Euramerica. Geol. Soc. Am. Bull., 98: 475-487.

Veizer, J., 1983. Geologic evolution of the Archean-Early Proterozoic Earth. In: J.W. Schopf (Editor), Earth's Earliest Biosphere: Its Origin and Evolution. Princeton Univ. Press, Princeton, N.J., pp. 240-259.

Veizer, J., 1988. The evolving exogenic cycle. In: C.B. Gregor, R.M. Garrels, F.T. Mackenzie and J.B. Maynard (Editors), Chemical Cycles in the Evolution of the Earth. Wiley, New York, N.Y., pp. 175-220.

Veizer, J., 1989. Strontium isotopes in seawater through time. Annu. Rev. Earth Planet. Sci., 17: 141-167.

Veizer, J., Compston, W., Hoefs, J. and Nielsen, H., 1982. Mantle buffering of the early oceans. Naturwissenschaften, 69: 173-180. 
Veizer, J., Hoefs, J., Lowe, D.R. and Thurston, P.C., 1989a. Geochemistry of Precambrian carbonates: II. Archean greenstone belts and Archean sea water. Geochim. Cosmochim. Acta, 53: 859-871.

Veizer, J., Hoefs, J., Ridler, R.H., Jensen, L.S. and Lowe, D.R., 1989b. Geochemistry of Precambrian carbonates: I. Archean hydrothermal systems. Geochim. Cosmochim. Acta, 53: 845-857.

Veizer, J. and Jansen, S.L., 1979. Basement and sedimentary recycling and continental evolution. J. Geol., 87: 341-370.

Volk, T., 1987, Feedbacks between weathering and atmospheric $\mathrm{CO}_{2}$ over the last 100 million years. Am. J. Sci., 287: 763-779.

Volk, T., 1989. Rise of angiosperms as a factor in long-term cooling. Geology, 17: 107-110.

Walker, J.C.G., 1974. Stability of atmospheric oxygen. Am. J. Sci., 274: 193-214.

Walker, J.C.G., 1977. Evolution of the Atmosphere. Macmillan, New York, 318 pp.

Walker, J.C.G., 1980. The oxygen cycle. In: O. Hutzinger (Editor), The Natural Environment and the Biogeochemical Cycles. Springer, Berlin, pp. 87-104.

Walker, J.C.G., 1982. Climatic factors on the Archean earth. Palaeogeogr., Palaeoclimatol., Palaeoecol., 40: 1-11.

Walker, J.C.G., 1983a. Possible limits on the composition of the Archaean ocean. Nature, 302: 518-520.

Walker, J.C.G., 1983b. Carbon geodynamic cycle. Nature, 303: 730-731.

Walker, J.C.G., 1984a. How life affects the atmosphere. BioScience, 34: 486-491.

Walker, J.C.G., 1984b. Suboxic diagenesis in banded iron formations. Nature, 309: 340-342.

Walker, J.C.G., 1985. Carbon dioxide on the early earth. Origins of Life, 16: 117-127.

Walker, J.C.G., 1987. Was the Archaean biosphere upside down? Nature, 329: 710-712.

Walker, J.C.G., 1978. The early history of oxygen and ozone in the atmosphere. Pure Appl. Geophys., 117: 498-512.

Walker, J.C.G., 1989. The geological record of atmospheric evolution. Indian J. Radio Space Res., 17: 147-154.

Walker, J.C.G., 1990a. Feedback processes in the biogeochemical cycles of carbon. In: S.H. Schneider (Editor), Science of Gaia. MIT Press, Cambridge, in press.

Walker, J.C.G., 1990b. Origin of an inhabited planet. In: J. Jones and H. Newson (Editors), Origin of the Earth. LPI, Houston, Tex., in press.

Walker, J.C.G. and Brimblecombe, P., 1985. Iron and sulfur in the pre-biologic ocean. Precambrian Res., 28: 205-222.
Walker, J.C.G. and Drever, J.I., 1988. Geochemical cycles of atmospheric gases. In: B. Gregor and J.B. Maynard (Editors), Chemical Cycles in the Evolution of the Earth. Wiley, New York, N.Y., pp. 55-76.

Walker, J.C.G., Hays, P.B. and Kasting, J.F., 1981. A negative feedback mechanism for the long-term stabilization of Earth's surface temperature. J. Geophys. Res., 86: 9776-9782.

Walker, J.C.G., Klein, C., Schidlowski, M., Schopf, J.W., Stevenson, D.J. and Walter, M.R., 1983. Environmental evolution of the Archean-Early Proterozoic Earth. In: J.W. Schopf (Editor), Earth's Earliest Biosphere: Its Origin and Evolution. Princeton Univ. Press, Princeton, N.J., pp. $260-290$.

Walker, J.C.G. and Lohmann, K.C., 1989. Why the oxygen isotopic composition of sea water changes with time. Geophys. Res. Lett., 16: 323-326.

Walker, J.C.G. and Zahnle, K.J., 1986. Lunar nodal tide and distance to the moon during the Precambrian. Nature, 320: $600-602$.

Walsh, M.M. and Lowe, D.R., 1985. Filamentous microfossils from the 3,500-Myr-old Onverwacht Group, Barberton Mountain Land, South Africa. Nature, 314: 530-532.

Walter, M., 1979. Precambrian glaciation. Am. Sci., 67: 142.

Walter, M.R., 1983. Archean stromatolites: Evidence of the Earth's earliest benthos. In: J.W. Schopf (Editor), Earth's Earliest Biosphere: Its Origin and Evolution. Princeton Univ. Press, Princeton, N.J., pp. 187-213.

Wilkinson, B.H. and Walker, J.C.G., 1989. Phanerozoic cycling of sedimentary carbonate, Am. J. Sci., 289: 525-548.

Williams, G.E., 1980. Effects of the Earth's rotation rate on climate. Nature, 286: 309-310.

Wilson, T.R.S., Thomson, J., Hydes, D.J., Colley, S., Culkin, F. and Sorensen, J., 1986. Oxidation fronts in pelagic sediments: Diagenetic formation of metal-rich layers. Science, 232: 972-975.

Zahnle, K.J., 1986. Photochemistry of methane and the formation of hydrocyanic acid $(\mathrm{HCN})$ in the Earth's early atmosphere. J. Geophys. Res., 91: 2819-2834.

Zahnle, K.J. and Walker, J.C.G., 1982. The evolution of solar ultraviolet luminosity. Rev. Geophys. Space Phys., 20: $280-292$.

Zahnle, K.J and Walker, J.C.G., 1987. A constant daylength during the Precambrian Era? Precambrian Res., 37: 95105. 